\title{
A STUDY OF THE ACTION OF AMMONIUM CHLORID AND ORGANIC MERCURY COMPOUNDS
}

\author{
BY NORMAN M. KEITH AND MARY WHELAN 1 \\ (From the Division of Medicine, Mayo Clinic)
}

(Received for publication May 29, 1926)

The elimination of urine from the body is not the function of the kidney alone: the blood and the tissues are profoundly concerned. The blood may be considered the connecting link between the other two. The concentration in the blood of those substances which eventually appear in the urine must fluctuate with variations in the chemical state of either the tissues or the kidney or both. It is conceivable, therefore, that an absolutely, or apparently, identical chemical disturbance of the blood might result from either chemical changes in the tissues or disturbance of the excretory function of the kidneys. The general problem of the site of initiation of disease characterized by retention of urinary elements is thus complicated by the possibility that fundamentally different diseases may present the same superficial appearance.

The problem became still more intricate with the demonstration that retention of urea does not parallel retention of salt and water. Edema may be accompanied by normal excretion of urea, and normal urea content in the blood; urea may be retained without edema and even without serious anatomic changes in the kidneys; salt may be retained without edema being demonstrable.

The effect of diuretics is similarly difficult to explain. Diuresis can be produced by those which are known to increase blood-flow and by those which cannot be shown to have any such primary effect. It is impossible, therefore, to explain diuresis in every instance on the same hypothesis. The newer diuretics, ammonium chlorid and

' Fellow in Chemistry, The Mayo Foundation. 
novasurol, ${ }^{2}$ have been thought to act in a purely chemical way, by affecting the threshold of excretable bodies in the blood, and the acidbase equilibrium in the blood and tissues. Study of the chemical state of the blood cannot be divorced from consideration of the chemical reactions in the tissues. Whether these diuretics act on the tissues, the blood or the kidney is so important a problem that its elucidation will probably go a long way toward settling the whole question of the formation of urine.

Certain of the chemical constituents of the blood, like urea, will be excreted as soon as they appear; they have no threshold. Others, like the inorganic salts and glucose, must attain a fairly definite level before any escapes. This threshold varies in different individuals, and in the same person at different periods, even in health; in certain diseases the threshold is profoundly altered for one or more of them, even for those that normally have no threshold. This disturbance in the threshold of urea or salts may be associated with marked changes in the acid-base equilibrium of the blood and tissues. In acidosis the carbon dioxid combining-power of the plasma is decreased by acid entering the blood, although the hydrogen-ion concentration may be kept normal by the buffer system.

The effect of these newer diuretics on water retained in the interstices of the body is quite remarkable. Here again, if the mechanism of this action can be explained, the cause of the retention will be clear. There is some relation between the excretion of salts and the excretion of water; edema is often associated with chemical changes in the blood. Haldane found that the ingestion of ammonium chlorid by a normal man caused acidosis, as well as increase in urinary excretion, and he attributes this diuresis to the acidosis.

The object of the present study is to determine what chemical changes, especially in the content of salts and their ions, occurred in the blood and urine during the reduction of ascites and edema by the use of ammonium chlorid and novasurol, singly and in combination, and to compare them with the effects produced by the same medication in the normal.

2 Novasurol and salyrgan were used in these experiments. Novasurol is a double salt of sodium oxymercuri-o-chlorphenoxy-acetate with diethylbarbituric acid. Salyrgan is mercuric acetate-salicylallylamid-o-acetate of sodium. 


\section{AMMONIUM CHLORID}

Haldane's experiment in which he ingested ammonium chlorid in amounts varying from 5 to 55 grams on six occasions resulted in marked acidosis, as indicated by a fall in the alveolar carbon dioxid and in the carbon dioxid capacity of the blood, and an increase in the excretion of acid, ammonia and phosphates. Baird, Douglas and Haldane made similar observations a little later. Gamble, Blackfan and Hamilton noted acidosis, an increase in plasma chlorid, and a decrease in plasma carbon dioxid in children after they had

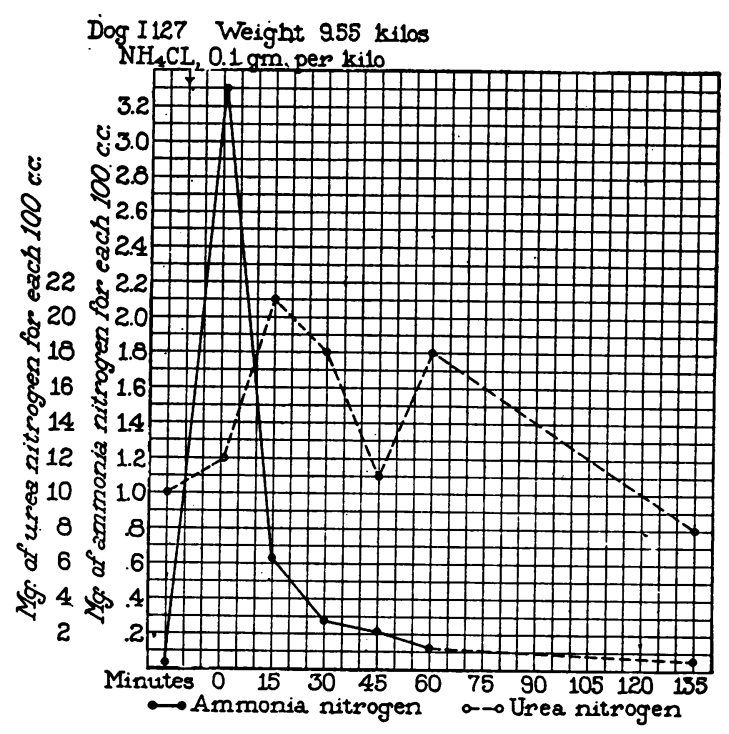

Fig. 1. Dog I127. Intravenous Injection of Ammonium Chlorm, Showing tHe Relatron between tHe AmMonia aNd UREa Concentration IN THE

Blood. (TABLE 1)

taken 5.8 grams of ammonium chlorid a day for four days. They observed also that there was no appreciable loss of plasma base. They attribute the acidosis, evidenced by the lowering of the plasma carbon dioxid almost wholly to increase of chlorid.

The present studies on ammonium chlorid were carried out on a normal volunteer, on patients, and on dogs. In all cases control periods preceded the giving of ammonium chlorid. The dogs were 


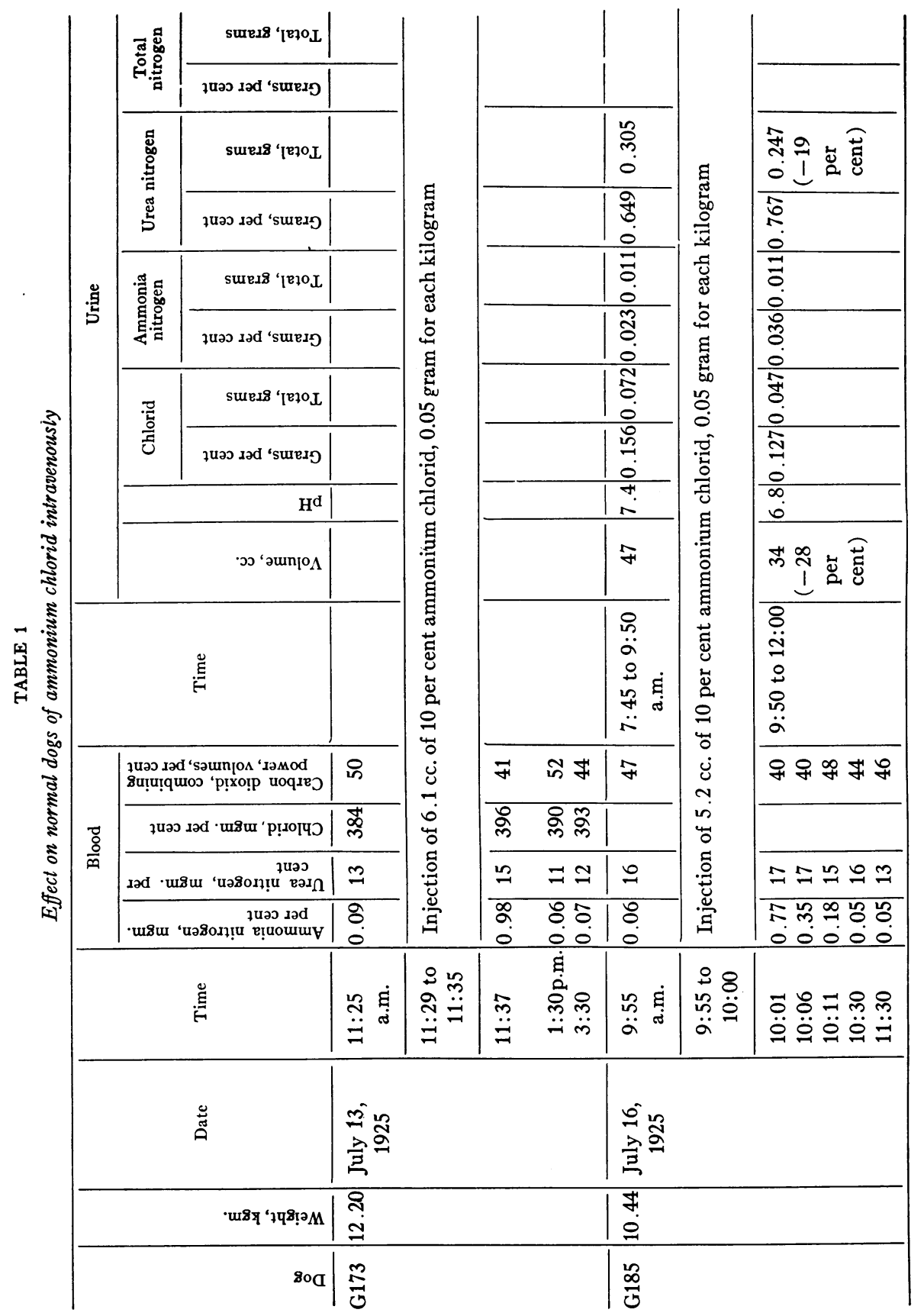




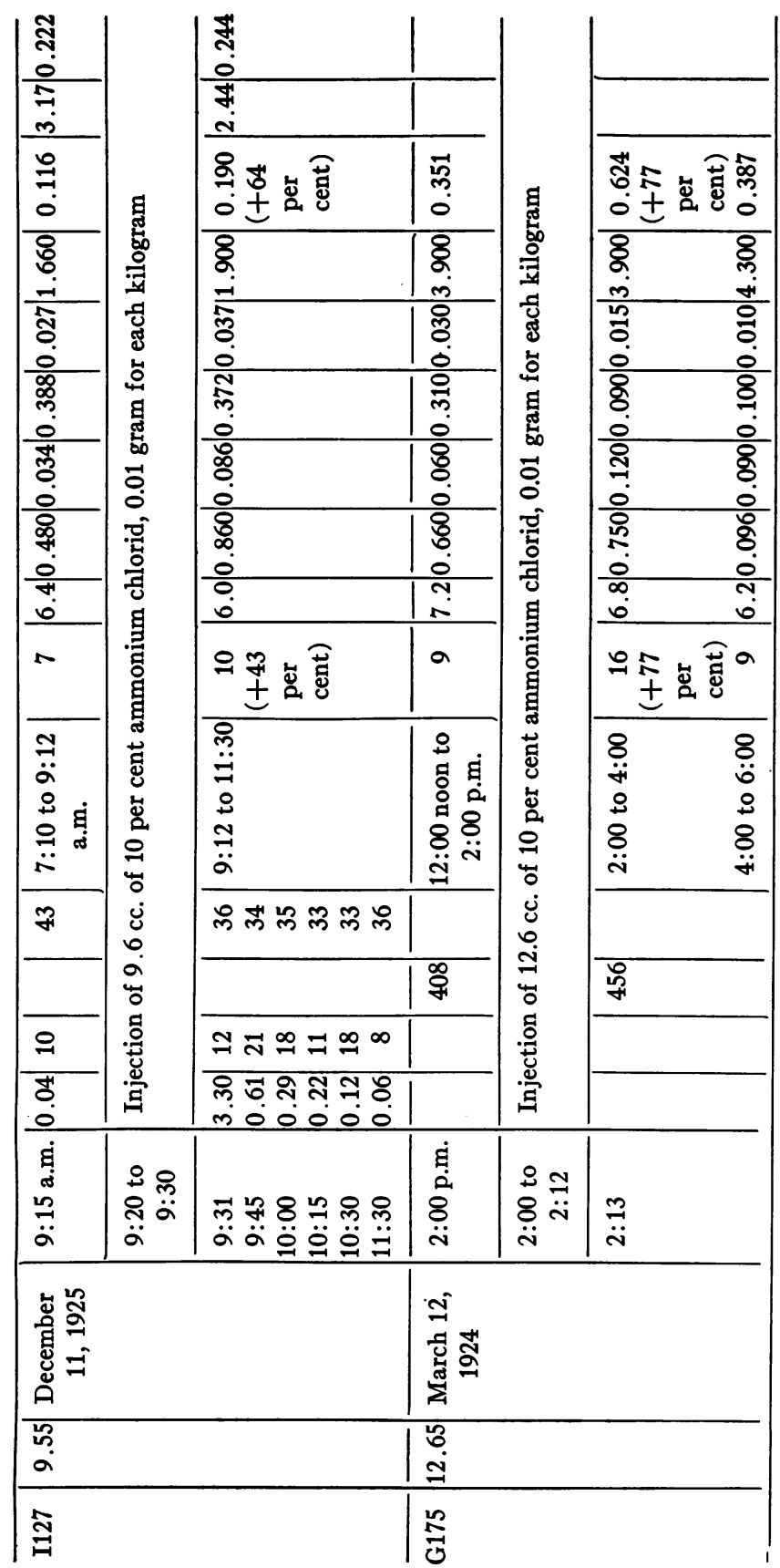




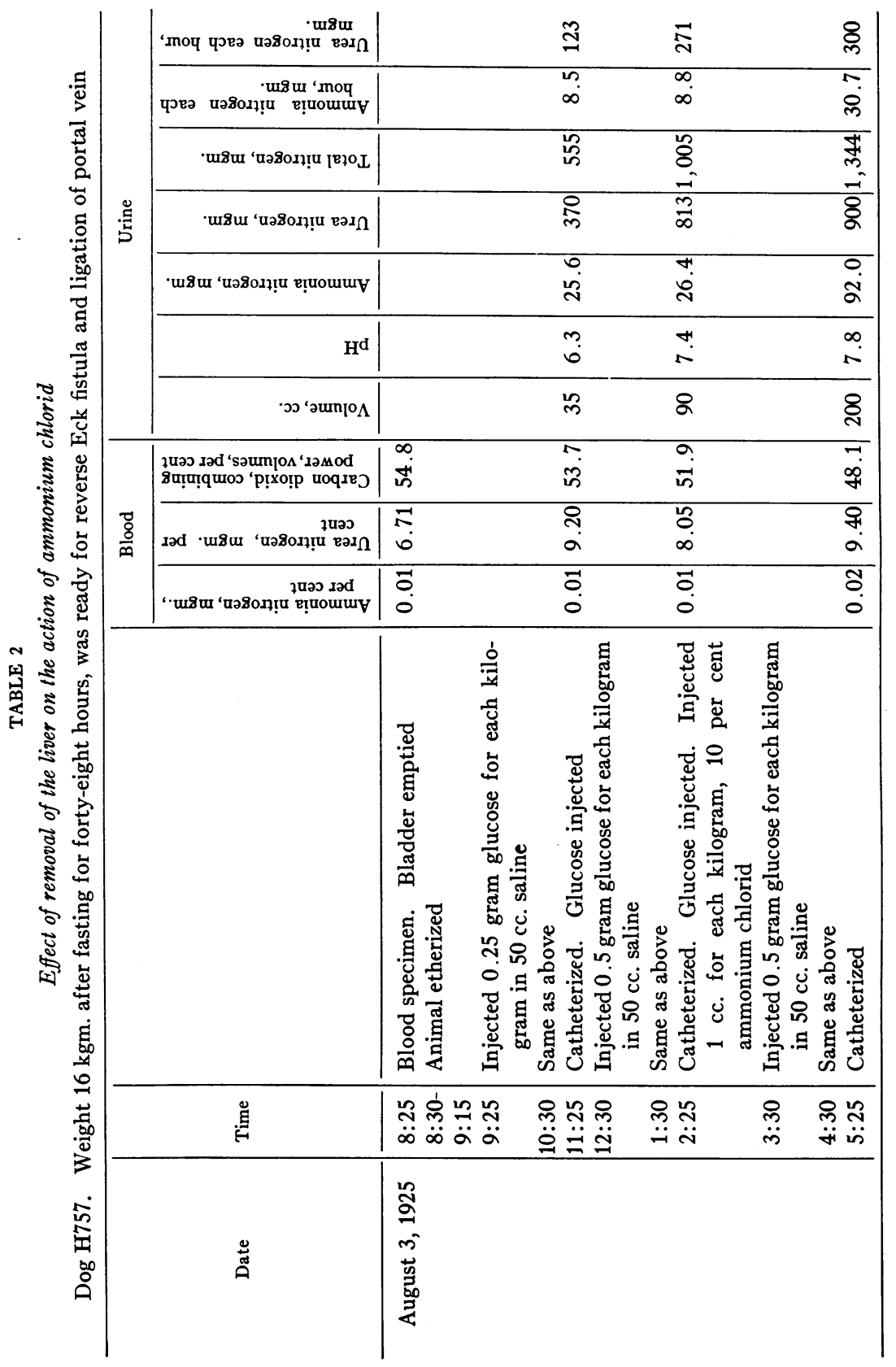




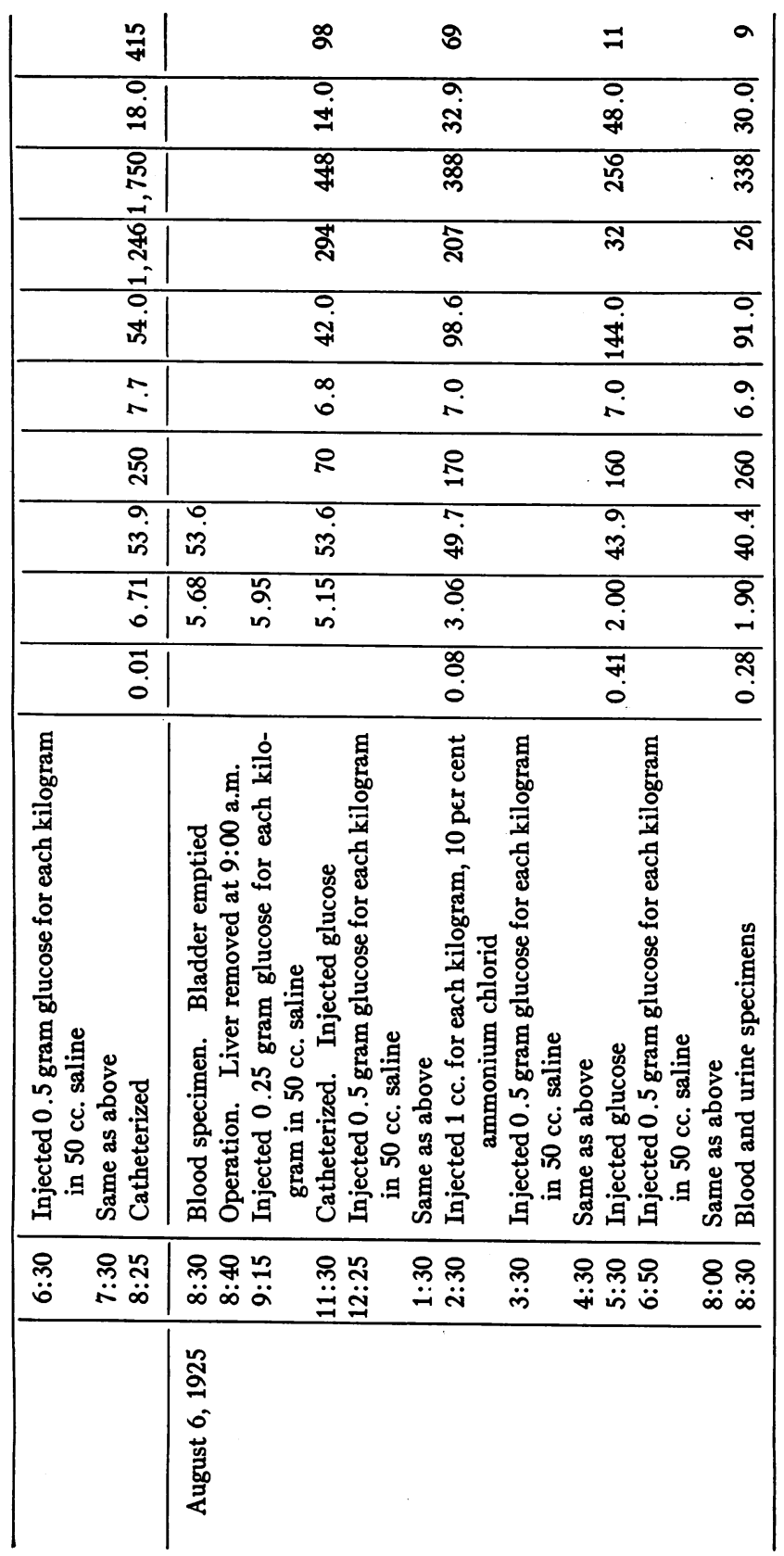


given no food during the eighteen hours preceding the experiment and until the study period was completed (usually four hours after the intravenous injection of 10 per cent ammonium chlorid, 0.05 to 0.1 gram (for each kilogram). Human subjects were kept on weighed low-salt, low-fluid diets ${ }^{3}$ both before and during the ingestion of ammonium chlorid. The average usual dose of ammonium chlorid was 9 grams a day. The actual total amount ingested in one case was 364 grams over a continuous period of forty-two days. During both control and experimental periods studies of the blood and urine were made.

Blood. Ammonia was determined in the blood of dogs on three occasions, and all the findings were similar. The concentration of ammonia nitrogen in the blood rose immediately after the injection, reaching a maximum of $3.3 \mathrm{mgm}$. for each $100 \mathrm{cc}$. in two minutes, but dropped so rapidly that in fourteen minutes it was reduced to $0.61 \mathrm{mgm}$. or one-fifth the maximal value. The rapid drop continued for from half an hour to two hours, until the concentration became normal. Blood-urea nitrogen did not show a marked change even at the end of two hours in dogs G173 and G185, but with the larger injection in dog I127 (fig. 1) it rose from 10 to $21 \mathrm{mgm}$. Plasma chlorids did not change appreciably; the carbon dioxid combiningpower of the plasma showed a slight initial drop, which in some cases persisted for two hours. Urine collected at intervals of two hours before and after the injection of ammonium chlorid showed an increase in volume in two experiments and a decrease in a third, an increase in hydrogen-ion concentration in all, and an increase in the concentration of chlorids in two experiments. The ammonium nitrogen did not show any definite constant change; the urea nitrogen concentration remained the same or increased. The latter increase is in agreement with previous results $(18,57)$.

Experiments of short duration give a fair idea of the manner in which the injected salt is distributed in the blood. In the case of ammonium chlorid both of the injected ions leave the blood stream

${ }^{3}$ The actual food of these diets contained approximately $800 \mathrm{cc}$. of water, and from 0.6 to 0.8 gram chlorid, from 0.5 to 0.7 gram sodium and from 1.6 to 1.8 grams potassium. Complete details in article. "The therapeutic use of diets low in water and mineral content" (31). 


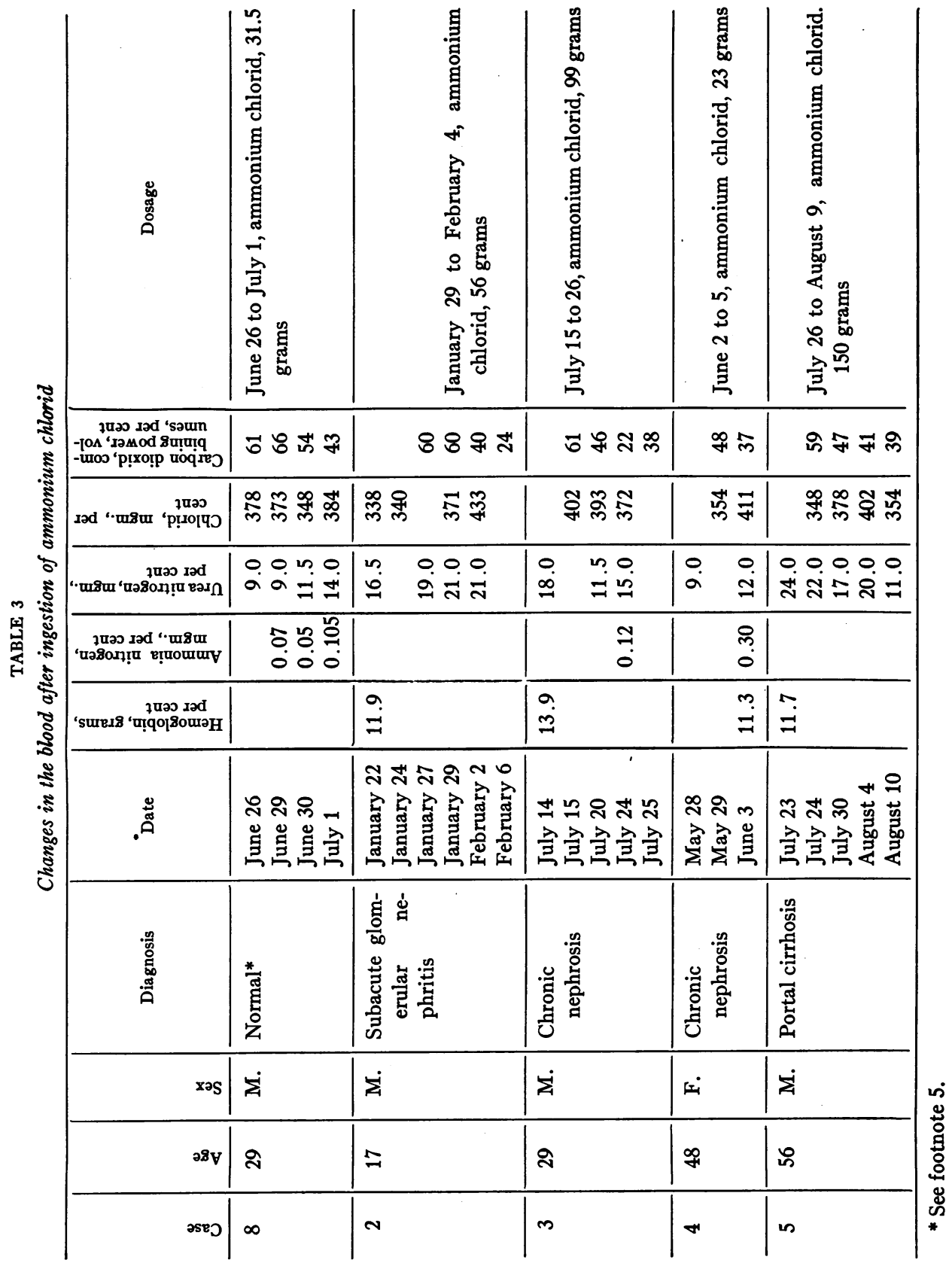


with remarkable rapidity, the chlorid so rapidly that a definite increase in plasma chlorids may not be detected two minutes after injection. The ammonia nitrogen shows an increase but becomes normal in from half an hour to two hours.

The rapid decrease in the ammonia with concomitant rise in the urea content of the blood and increased excretion of urea in the urine in dogs I127 and G175 indicates a quick formation of urea from the ammonium ion of the injected salt. An experiment was carried out by Bollman, Mann and Magath (dog A757, table 2) to ascertain whether urea could be formed from ammonium chlorid in a dog whose liver has been removed. The control experiment had been made after the animal's inferior vena cava and portal vein had been ligated. After removal of the liver and the injection of ammonium chlorid, urea formation diminished and the ammonia nitrogen in the blood remained abnormally high for six hours. The result of this experiment indicates that the ammonium ion is not readily synthesized to urea in the dog with its liver removed, quite the contrary to what occurs in the normal dog. This was to be anticipated from the work of Bollman, Mann and Magath.

In human patients after prolonged ingestion of ammonium chlorid practically all showed an increase in blood-urea (table 3). A normal man (Case 8) ingested 31.5 grams of ammonium chlorid in three days (10.5 grams a day) and his blood-urea nitrogen rose from 9 to $14 \mathrm{mgm}$. for each $100 \mathrm{cc}$. However, one patient (case 5, table 3) having cirrhosis of the liver with ascites showed a gradual decrease in blood-urea even during the continuous ingestion of 150 grams of the salt for fifteen days. This variation in the blood-urea content after ingestion of ammonium chlorid has suggested a possible relationship between the urea content of the blood, and the presence or absence of water available for its elimination. During this period in the same case, there was no marked disturbance in the carbon dioxid capacity of the plasma. The carbon dioxid combining power of the plasma was 39 per cent by volume at the end of fifteen days, having been 41 per cent by volume on the eleventh day and 59 at the beginning of the period. Nevertheless, in most cases the carbon dioxid combining-power of the plasma underwent a decided drop about the fourth or fifth day after the daily ingestion of the usual 
amount of the salt, 9 to 10 grams each day (a total of about 40 grams). The plasma chlorid was usually increased. This increase was particularly marked in cases in which the plasma chlorid was low at the beginning of the ingestion of the ammonium chlorid.

In a few cases the ammonia-nitrogen content of the blood was determined before and after several days' ingestion of the ammonium chlorid. A demonstrable increase in the blood-ammonia has not been encountered often. Even after the ingestion of 81 grams of ammonium chlorid ( 9 grams each day) in one case the ammonia nitrogen of the blood was only $0.12 \mathrm{mgm}$. for each $100 \mathrm{cc}$. A value as high as $0.30 \mathrm{mgm}$. was obtained in a single case. If the ingestion of ammonium chlorid should result in the accumulation of ammonia in the blood the usual methods for the determination of urea would not give the true value of the blood-urea. But the small values which have been obtained thus far in man would not produce an appreciable difference in the urea values since even the highest amount, $0.30 \mathrm{mgm}$. of ammonia nitrogen, would be equal to only $0.65 \mathrm{mgm}$. of urea.

In this series no studies on the sodium, potassium, calcium, and magnesium in the serum were made, but a recent study in a single case (case 6, table 4) after the patient had ingested 39 grams of ammonium chlorid showed no change in the sodium in the serum. In a previous experimental study on dogs, the sodium, potassium, calcium, magnesium and chlorids were determined immediately after the intravenous injection of ammonium chlorid, but no change in these ions was noted. Gamble, Blackfan and Hamilton have also shown that ammonium chlorid causes no appreciable change in the amount of fixed base in the plasma.

Crine. The ingestion of ammonium chlorid by a normal subject (case 8 ) and by two patients (cases 6 and 7) produced no change in the volume of the urine, whereas in the other patients (cases 2, 4, and 5) there was a definite diuresis. In the latter the urine nearly doubled in volume and the volume remained large as long as the salt was ingested (table 4). The cases include nephritis, nephrosis with edema, cirrhosis of the liver with ascites and edema, and endocarditis with ascites and edema. During the first period (ingestion of ammonium chlorid) in cases 2, 4 and 5, the excretion of urine equalled 
TAB

The effect of ammonizm

\begin{tabular}{|c|c|c|c|c|c|c|c|c|c|c|c|c|c|c|}
\hline \multirow[b]{2}{*}{ Ð } & \multirow[b]{2}{*}{$\stackrel{8}{8}$} & \multirow[b]{2}{*}{ ๗ั } & \multirow{2}{*}{ Diagnosis } & \multirow[b]{2}{*}{ Date, 1925} & \multirow[b]{2}{*}{ 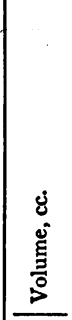 } & \multirow[b]{2}{*}{ 管 } & \multicolumn{2}{|c|}{ Chlorid } & \multicolumn{2}{|c|}{ Phosphorus } & \multicolumn{2}{|c|}{$\begin{array}{c}\text { Inorganic } \\
\text { sulphur as } \\
\mathrm{SO}_{3}\end{array}$} & \multicolumn{2}{|c|}{ Sodium } \\
\hline & & & & & & & 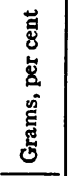 & 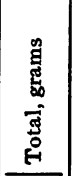 & 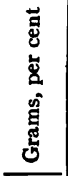 & 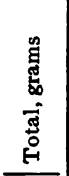 & 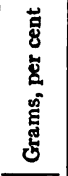 & है & 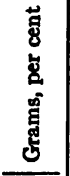 & हू. \\
\hline 8 & 29 & M. & Normal* & $\begin{array}{l}\text { June } 28 \\
\text { June } 29 \\
\text { June } 30 \\
\text { July } 1\end{array}$ & $\begin{array}{l}475 \\
500 \\
550 \\
550\end{array}$ & $\begin{array}{l}5.4 \\
5.4 \\
4.6 \\
4.6\end{array}$ & $\begin{array}{l}0.03 \\
0.07 \\
0.42 \\
0.68\end{array}$ & $\begin{array}{l}0.144 \\
0.360 \\
2.310 \\
3.760\end{array}$ & $\begin{array}{l}0.145 \\
0.147 \\
0.126 \\
0.140\end{array}$ & $\begin{array}{l}0.690 \\
0.735 \\
0.693 \\
0.770\end{array}$ & $\begin{array}{l}0.201 \\
0.252 \\
0.242 \\
0.211\end{array}$ & $\begin{array}{l}0.960 \\
1.260 \\
1.330 \\
1.610\end{array}$ & $\begin{array}{l}0.030 \\
0.013 \\
0.009 \\
0.028\end{array}$ & $\begin{array}{l}0.143 \\
0.065 \\
0.052 \\
0.151\end{array}$ \\
\hline 2 & 17 & M. & $\begin{array}{l}\text { Subacute glo- } \\
\text { merular ne- } \\
\text { phritis }\end{array}$ & $\begin{array}{l}\text { January } 28 \\
\text { January } 29 \\
\text { January } 30 \\
\text { January } 31 \\
\text { February } 1 \\
\text { February } 2 \\
\text { February } 3 \\
\text { February } 4 \\
\text { February } 5 \\
\text { February } 6 \\
\text { February } 7\end{array}$ & $\begin{array}{l}1,300 \\
2,200 \\
2,750 \\
2,900 \\
2,100 \\
2,100 \\
2,300 \\
1,850 \\
2,000 \\
1,150 \\
1,300\end{array}$ & $\begin{array}{l}6.2 \\
6.4 \\
6.0 \\
5.8 \\
5.4 \\
5.4 \\
5.0 \\
5.0 \\
4.6 \\
4.8 \\
4.8\end{array}$ & $\begin{array}{l}0.10 \\
0.07 \\
0.09 \\
0.13 \\
0.15 \\
0.19 \\
0.021 \\
0.23 \\
0.34 \\
0.32 \\
0.36\end{array}$ & $\begin{array}{l}1.300 \\
1.440 \\
2.480 \\
3.650 \\
2.550 \\
4.030 \\
4.600 \\
4.220 \\
6.840 \\
3.730 \\
4.680\end{array}$ & $\begin{array}{l}0.320 \\
0.020 \\
0.020 \\
0.018 \\
0.020 \\
0.025 \\
0.021 \\
0.021 \\
0.020 \\
0.032 \\
0.025\end{array}$ & $\begin{array}{l}0.416 \\
0.447 \\
0.550 \\
0.522 \\
0.420 \\
0.525 \\
0.483 \\
0.389 \\
0.404 \\
0.368 \\
0.325\end{array}$ & & & $\begin{array}{l}0.078 \\
0.057 \\
0.058 \\
0.079 \\
0.098 \\
0.107 \\
0.117 \\
0.123 \\
0.155 \\
0.157 \\
0.174\end{array}$ & $\begin{array}{l}1.010 \\
1.250 \\
1.600 \\
2.380 \\
2.060 \\
2.280 \\
2.690 \\
2.280 \\
3.100 \\
1.810 \\
2.160\end{array}$ \\
\hline 4 & 48 & F. & $\begin{array}{l}\text { Chronic } \\
\text { nephrosis }\end{array}$ & $\begin{array}{l}\text { May } 31 \\
\text { June } 1 \\
\text { June } 2 \\
\text { June } 3 \\
\text { June } 4 \\
\text { June 5 }\end{array}$ & $\begin{array}{r}700 \\
850 \\
1,400 \\
1,700 \\
900 \\
1,200\end{array}$ & $\begin{array}{l}5.8 \\
6.2 \\
5.4 \\
6.2 \\
6.0 \\
5.2\end{array}$ & $\begin{array}{l}0.29 \\
0.30 \\
0.56 \\
0.44 \\
0.46 \\
0.35\end{array}$ & $\begin{array}{l}2.020 \\
2.550 \\
5.340 \\
7.560 \\
4.080 \\
4.250\end{array}$ & $\begin{array}{l}0.060 \\
0.052 \\
0.030 \\
0.039 \\
0.042 \\
0.045\end{array}$ & $\begin{array}{l}0.420 \\
0.430 \\
0.420 \\
0.663 \\
0.378 \\
0.540\end{array}$ & $\begin{array}{l}0.058 \\
0.038 \\
0.030 \\
0.032 \\
0.033 \\
0.037\end{array}$ & $\begin{array}{l}0.406 \\
0.323 \\
0.404 \\
0.537 \\
0.299 \\
0.444\end{array}$ & $\begin{array}{l}0.180 \\
0.130 \\
0.190 \\
0.220 \\
0.140 \\
0.130\end{array}$ & $\begin{array}{l}1.270 \\
1.110 \\
2.700 \\
3.710 \\
1.230 \\
1.500\end{array}$ \\
\hline 5 & 56 & M. & Portal cirrhosis & $\begin{array}{l}\text { July } 25 \\
\text { July } 26 \\
\text { July } 27 \\
\text { July } 28 \\
\text { July } 29 \\
\text { July } 30 \\
\text { July } 31 \\
\text { August } 1 \\
\text { August } 2 \\
\text { August } 3 \\
\text { August } 4 \\
\text { August } 5 \\
\text { August } 6 \\
\text { August } 7 \\
\text { August } 8 \\
\text { August } 9 \\
\text { August } 10 \\
\text { August } 11\end{array}$ & $\begin{array}{r}850 \\
1,300 \\
1,100 \\
1,650 \\
1,500 \\
1,650 \\
1,500 \\
950 \\
960 \\
950 \\
400 \\
900 \\
650 \\
700 \\
700 \\
700 \\
675 \\
390\end{array}$ & $\begin{array}{l}5.0 \\
5.2 \\
5.2 \\
4.6 \\
5.0 \\
4.6 \\
4.6 \\
4.8 \\
4.6 \\
5.8 \\
5.0 \\
4.8 \\
5.2 \\
5.2\end{array}$ & $\begin{array}{l}0.59 \\
0.68 \\
0.71 \\
0.78 \\
0.74 \\
0.87 \\
0.87 \\
0.95 \\
0.86 \\
0.97 \\
0.95 \\
0.97 \\
0.92 \\
0.77\end{array}$ & $\begin{array}{r}7.620 \\
10.260 \\
9.740 \\
7.410 \\
7.320 \\
8.400 \\
3.550 \\
8.540 \\
7.340 \\
4.880 \\
6.420 \\
6.800 \\
6.200 \\
2.990\end{array}$ & & & & & & \\
\hline 6 & 22 & F. & $\begin{array}{l}\text { Chronic } \\
\text { nephrosis }\end{array}$ & $\begin{array}{l}\text { March } 12 \\
\text { March 13 } \\
\text { March } 14 \\
\text { March } 15 \\
\text { March } 16 \\
\text { March } 17\end{array}$ & $\begin{array}{l}650 \\
850 \\
450 \\
450 \\
600 \\
700\end{array}$ & $\begin{array}{l}6.8 \\
6.4 \\
6.2 \\
6.0 \\
5.8 \\
5.8\end{array}$ & $\begin{array}{l}0.42 \\
0.40 \\
0.73 \\
0.80 \\
0.87 \\
0.66\end{array}$ & $\begin{array}{l}2.330 \\
2.450 \\
3.290 \\
3.600 \\
5.360 \\
4.620\end{array}$ & $\begin{array}{l}0.070 \\
0.070 \\
0.105 \\
0.122 \\
0.083 \\
0.072\end{array}$ & $\begin{array}{l}0.455 \\
0.595 \\
0.743 \\
0.836 \\
0.498 \\
0.494\end{array}$ & & & $\begin{array}{l}0.367 \\
0.288 \\
0.325 \\
0.300 \\
0.249 \\
0.115\end{array}$ & $\begin{array}{l}2.390 \\
2.450 \\
1.460 \\
1.350 \\
1.490 \\
0.810\end{array}$ \\
\hline 7 & 35 & M. & $\begin{array}{l}\text { Chronic endocar- } \\
\text { ditis; poly- } \\
\text { cythemia }\end{array}$ & $\begin{array}{l}\text { May } 27 \\
\text { May } 28 \\
\text { May } 29 \\
\text { May } 30 \\
\text { May } 31\end{array}$ & $\begin{array}{l}600 \\
300 \\
600 \\
150 \\
500\end{array}$ & & & & & & & & & \\
\hline
\end{tabular}

† Full diet not taken.

- See Footnote 5. 
or exceeded the fluid intake. The patient (case 2) lost weight, almost 4 kilos in seven days. During the second period (no ammonium chloride and diet with increased salts and water) the fluid intake exceeded the excretion of urine. The patient gained in weight. The third period was a repetition of the first. The result in this case (case 2) brings out clearly the possible relation of the diet to treatment in cases of edema (table 5), since in our experience the cessation of ammonium chlorid ingestion rarely resulted in an immediate gain in weight when the diet was weighed and low in salt and fluid content.

TABLE 5

Combined effect of low-salt low-fluid diet and ammonium chlorid

Case 2. Subacute glomerular nephritis

\begin{tabular}{c|c|c|c|c|c|c|c}
\hline Period & Date, 1925 & Days & $\begin{array}{c}\text { Average } \\
\text { daily } \\
\text { fluid } \\
\text { intake, } \\
\text { cc. }\end{array}$ & $\begin{array}{c}\text { Average } \\
\text { daily } \\
\text { urine } \\
\text { excre- } \\
\text { tion, cc. }\end{array}$ & $\begin{array}{c}\text { Change } \\
\text { in } \\
\text { igight, } \\
\text { kgm. }\end{array}$ & $\begin{array}{c}\text { Total } \\
\text { ammo- } \\
\text { nium } \\
\text { chlorid, } \\
\text { grams }\end{array}$ & Diet \\
\hline 1 & $\begin{array}{l}\text { January 29 } \\
\text { February 4 to }\end{array}$ & 7 & 1,560 & 2,315 & -3.6 & 56 & $\begin{array}{l}\text { Weight, low-salt, low- } \\
\text { fluid }\end{array}$ \\
2 & $\begin{array}{l}\text { February 5 to 10 } \\
\text { February 11 to 18 }\end{array}$ & 6 & 2,025 & 1,258 & +1.4 & 0 & $\begin{array}{l}\text { Salt-free, not weighed } \\
\text { Weighed, low-salt, low- } \\
\text { fluid }\end{array}$ \\
\hline
\end{tabular}

In all cases there was a definite increase in the hydrogen-ion concentration of the urine. The greatest change occurred about the fifth day, after the ingestion of approximately 40 grams of ammonium chlorid, although in the normal subject the hydrogen-ion concentration changed from 5.4 to 4.6 on the second day after the ingestion of 21.0 grams of the salt.

The chlorid excreted was increased in all cases, both in concentration and total amount. The other inorganic anions $\left(\mathrm{SO}_{4}\right.$ and $\left.\mathrm{PO}_{4}\right)$ however, were very little affected, although usually the phosphates were slightly increased. Of the basic ions the most marked change was observed in sodium and potassium (table 4). In the normal subject there was a great increase in the excretion of potassium while the sodium actually diminished on the first two days. Gamble, Blackfan and Hamilton made the same observation after calcium chlorid had been ingested. When edema was present there was 
usually an increase in the sodium and potassium excreted, the increase in sodium being the more marked. Changes in calcium and magnesium were slight and difficult to evaluate. The total amounts excreted were slightly increased. The sum of the basic ions, calculated as cubic centimeters of one-tenth normal alkali, always showed a progressive increase after the ingestion of ammonium chlorid, indicating that inorganic basic ions are excreted in large amounts in combination with chlorid. Ammonia nitrogen, urea nitrogen, and total nitrogen increased in all cases, the increase in the last being accounted for by the nitrogen in the ammonium chlorid ingested.

After the ingestion of ammonium chlorid a certain amount of the ammonia appears in the urine; the greater proportion, however, is excreted as urea. The hydrochloric acid which is formed causes acidosis, which in turn causes an increase in the excretion of ammonia and of fixed base. Of the fixed base, sodium is as a rule the chief component, but, if a sufficient amount is not available, an increase in the excretion of potassium occurs.

Basal metabolism. Determinations of the basal metabolic rate were made on three different mornings while a patient aged fortyeight, with chronic nephritis and edema, was recieving 10 grams of ammonium chlorid daily. After he had taken 30 grams the rate was +1 , after 40 grams, -5 , after 65 grams, 0 . Two hours before the last rate was determined the patient had received 5 grams of ammonium chlorid. Such results indicate that the ingestion of ammonium chlorid by patients with nephritis and edema has no measurable effect on the basal metabolic rate.

\section{ORGANIC MERCURY COMPOUNDS ${ }^{4}$}

Saxl and Heilig were the first to discover that novasurol caused a marked diuretic response in cases of cardiac edema. They demonstrated a relative and an absolute increase in the chlorids excreted in the urine. Bohn showed that this occurred in rabbits. Nonnenbruch and Mühling showed that in normal persons novasurol caused an

4 The organic mercury compounds used in this investigation were novasurol and salyrgan. The former was supplied by the Winthrop Chemical Company, New York, and the latter by Metz and Company, New York. 


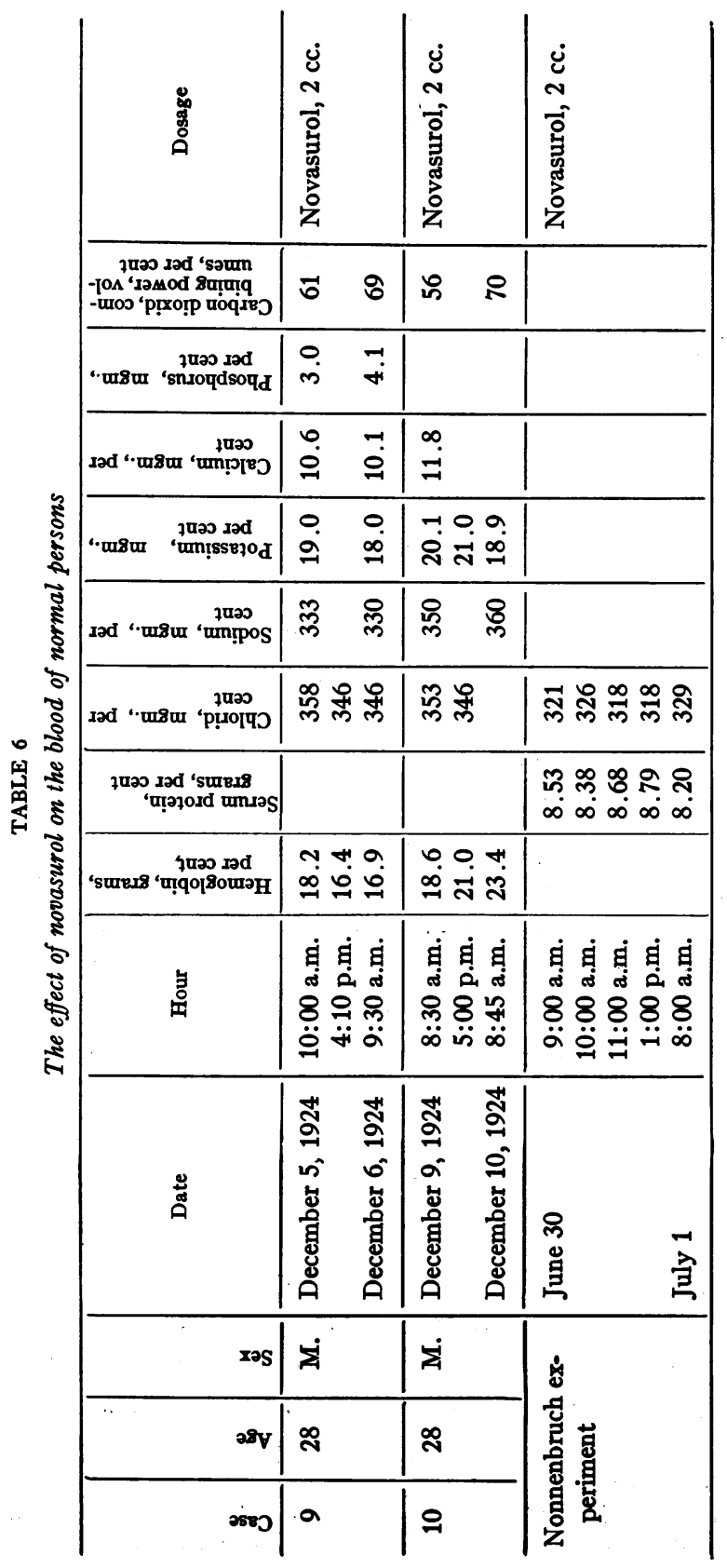


increase in the chlorids excreted in the urine, but the latter showed that diuresis did not always occur. We ourselves confirmed these observations in two normal subjects and a dog. In further studies we found that there was a relative and absolute increase in the output of sodium. Saxl and Heilig, and Mühling, emphasized the early appearance of mercury qualitatively in the urine after the administration of novasurol. We have been able to recover quantitatively a large percentage of the mercury injected ( 48.5 to 85.6$)$ in the urine of the subsequent twenty-four hours.

Blood. In the present study the normal subjects and patients were under the same control conditions with regard to diet and fluid intake as those in the previous experiments with ammonium chlorid. Analysis of the blood and serum in two normal men before and after the injection of novasurol (table 6) showed no constant changes in the concentration of hemoglobin, chlorid, sodium, potassium, calcium or phosphates. The carbon dioxid combining-power of the plasma remained within normal limits. Nonnenbruch in an experiment conducted under similar control conditions noted no variation in the chlorid concentration, but a slight rise in the protein content during diuresis. No significant changes in the rest nitrogen, uric acid or creatinin were noted by Mühling.

Studies of the blood in three cases of ascites similarly failed to show any constant changes (table 7). These inconstant findings are essentially in agreement with previous studies reported by Saxl and Heilig, Mühling, and Bleyer. Crawford and McIntosh report a fall in plasma chlorid for from three and a half to four and a half hours after the injection of novasurol with a later slow rise, also a fall in serum protein in the first one and a half hours after the injection in two cases of edema of cardiac origin. That such early changes occur invariably has still to be corroborated by further work. The constancy of the normal values for the carbon dioxid combining-power of the plasma in our cases is worthy of note.

Urine. An experiment was made on a normal dog (dog G619) to ascertain the effect of novasurol on the urine (table 8). The animal did not receive food or water during the experiment which lasted twenty-four hours. The time was divided into three eight-hour periods, and a specimen of urine was obtained by catheter at the end 


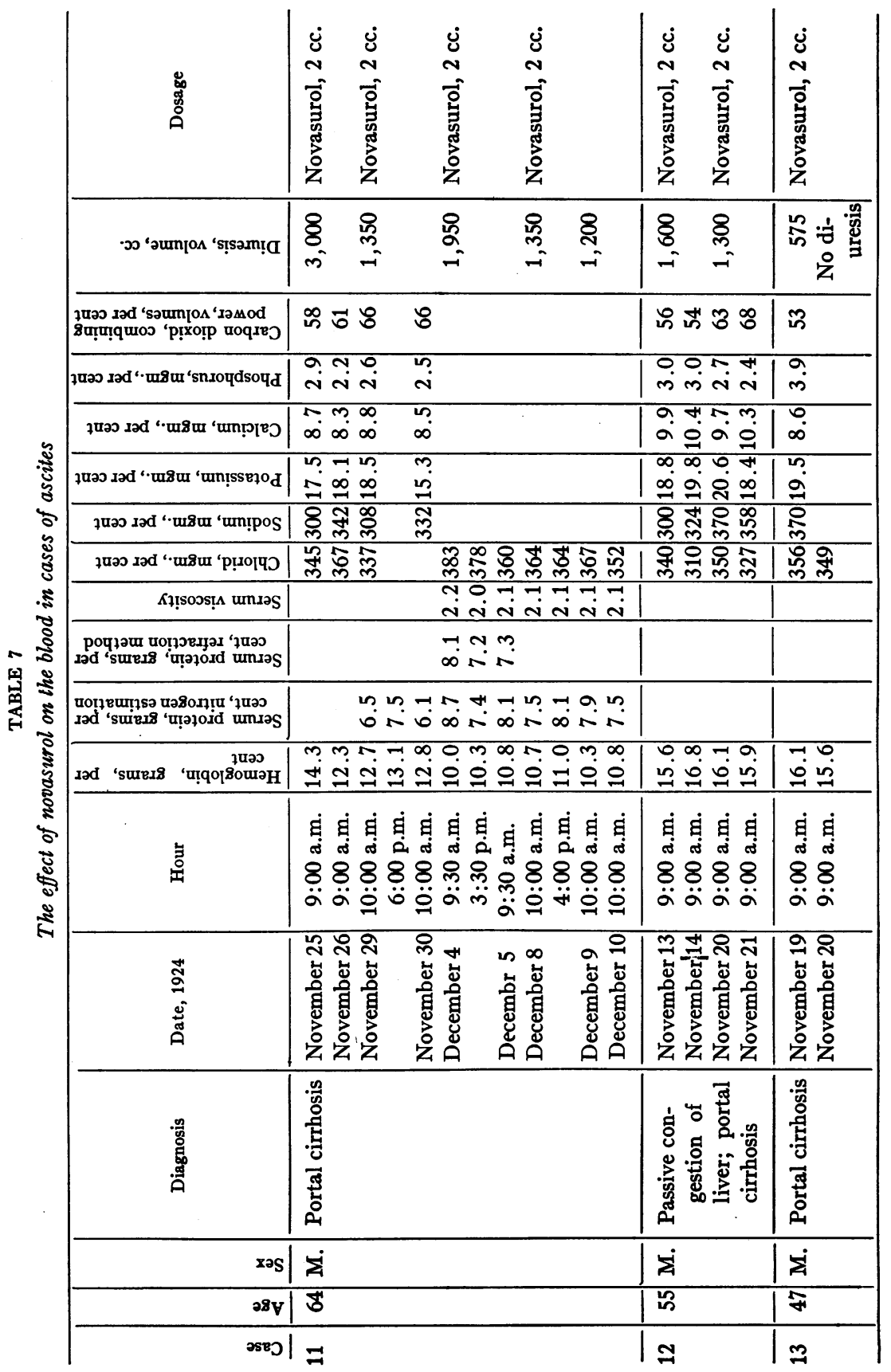



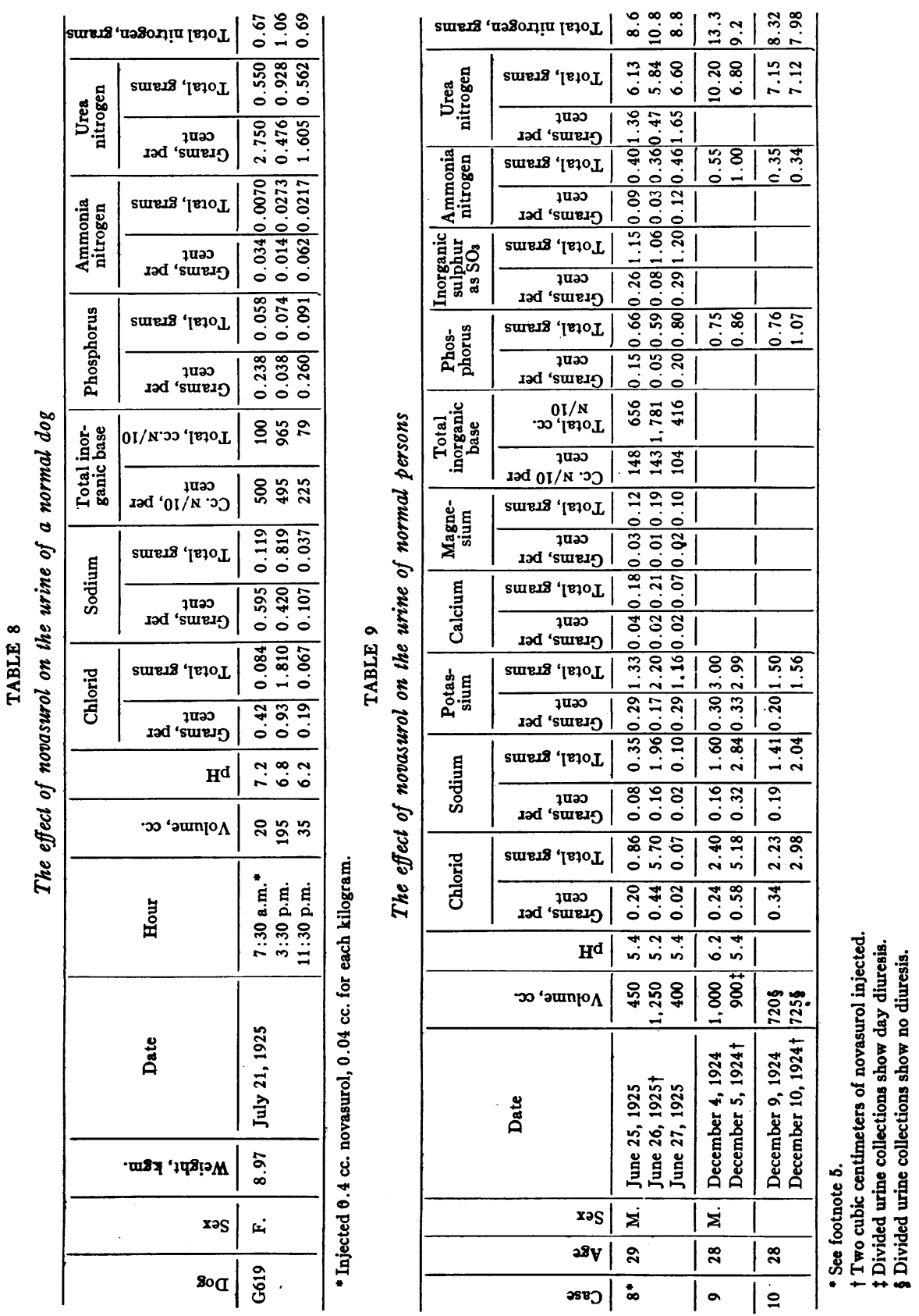

THE JOURNAL OF CLINICAL INVEgTIGATION, VOL. III, NO. 1 
of each period. Novasurol was injected at the beginning of the second period. Thus, we had a control period of urine excretion before and after the exhibition of novasurol. Following the injection of novasurol marked diuresis occurred, accompanied by a high concentration of chlorid, sodium and total inorganic fixed base in the urine which was maintained, resulting in a striking increase in their total excretion. A moderate rise in the output of nitrogen, urea and ammonia with little change in the amount of phosphorus or in the hydrogen-ion concentration also occurred. The noteworthy urinary findings in the third period were a decrease in the volume of the urine and in the output of chlorids, sodium and total inorganic base, even below that of the first control period. The phosphorus excreted was slightly increased while the urea and total nitrogen approximated those of the first period.

A similar experiment was carried out over a three-day period in a normal $\operatorname{man}^{5}$ (case 8 , table 9). His diet was as accurately controlled as that for the patients in the series. As in the dog, novasurol caused an increase in the excretion of water, chlorids, sodium, total inorganic base, and total nitrogen. The excretion of potassium and magnesium was increased, but there was no appreciable change in the output of calcium, phosphorus, sulphate, urea or ammonia. The hydrogenion concentration was unchanged. On the third day, or post-novasurol period, the excretion of chlorids, sodium and total inorganic base fell below that of the first day. This result corresponded closely to that obtained in the experiment on dog G619. Nonnenbruch's experiment with a dry controlled diet in a normal student gave similar results as to the chlorid. He did not carry out the other analyses. The continuous increase in the excretion of potassium is of note.

The urinary findings of two other normal subjects (cases 9 and 10, table 9) correspond to the results in the two previous experiments except that frank diuresis was not produced and the excretion of potassium remained unaltered. In one normal subject (case 9) the urine excreted during the day was increased, but the twenty-fourhour output approximated that of the previous twenty-four hours.

${ }^{5}$ An active healthy physician with the findings of a normal man except for a mild type of orthostatic albuminuria. 
Bleyer made a similar observation. In case 10 divided specimens failed to show any evidence of diuresis during the entire twenty-four hours. Under like control conditions, Mühling reported similar results. The urinary excretion of mercury was determined in a normal subject after the injection of $2 \mathrm{cc}$. of novasurol; 85.6 per cent of the amount injected was recovered in the twenty-four hour specimen of urine.

The urinary findings in seven cases of edema and ascites and one of myxedema following the injection of novasurol are given in table 10. After ten of the thirteen injections frank diuresis occurred. Continuous diuresis, of forty-eight hours, occurred on three occasions in one case (case 11, table 10). Even more prolonged periods of diuresis occurred, but they were infrequent and their exact significance was difficult to determine. In case 13 the volume of urine was not increased, yet there was a distinct rise in the concentration and total output of chlorids, as in the normal subject (case 10, table 9). Two reactions occurred in case 17 (table 10). With the early injections diuresis was produced, but subsequently the volume of urine and output of chlorids were little affected. A similar failure in diuretic action occurred in case 18 (table 10). This failure of novasurol to cause an increase in the excretion of water and chlorids in the urine was associated in both case 17 and case 18 with a concentration of the plasma chlorid of $276 \mathrm{mgm}$. for each $100 \mathrm{cc}$., well below the normal renal threshold, $336 \mathrm{mgm}$.

Urinalysis before, during, and after diuresis in these cases gave results closely simulating those in the normal subject (case 8 , table 9). There was the marked increase in water, chlorids, sodium and total inorganic base. The excretion of potassium was variable, being usually, but not always, increased. In case 12 (table 10) it was actually decreased after the first injection of novasurol, and after the second injection the output remained unaltered.

The excretion of phosphate was characterized by a decrease in concentration with little gross change in the total output. The excretion of sulphate, estimated in case 14 (table 10) was unchanged. 'The excretion of urea, ammonia and total nitrogen was inconstant. Changes in the hydrogen-ion concentration were minor in degree. The post-novasurol period showed a decrease in the excretion of 


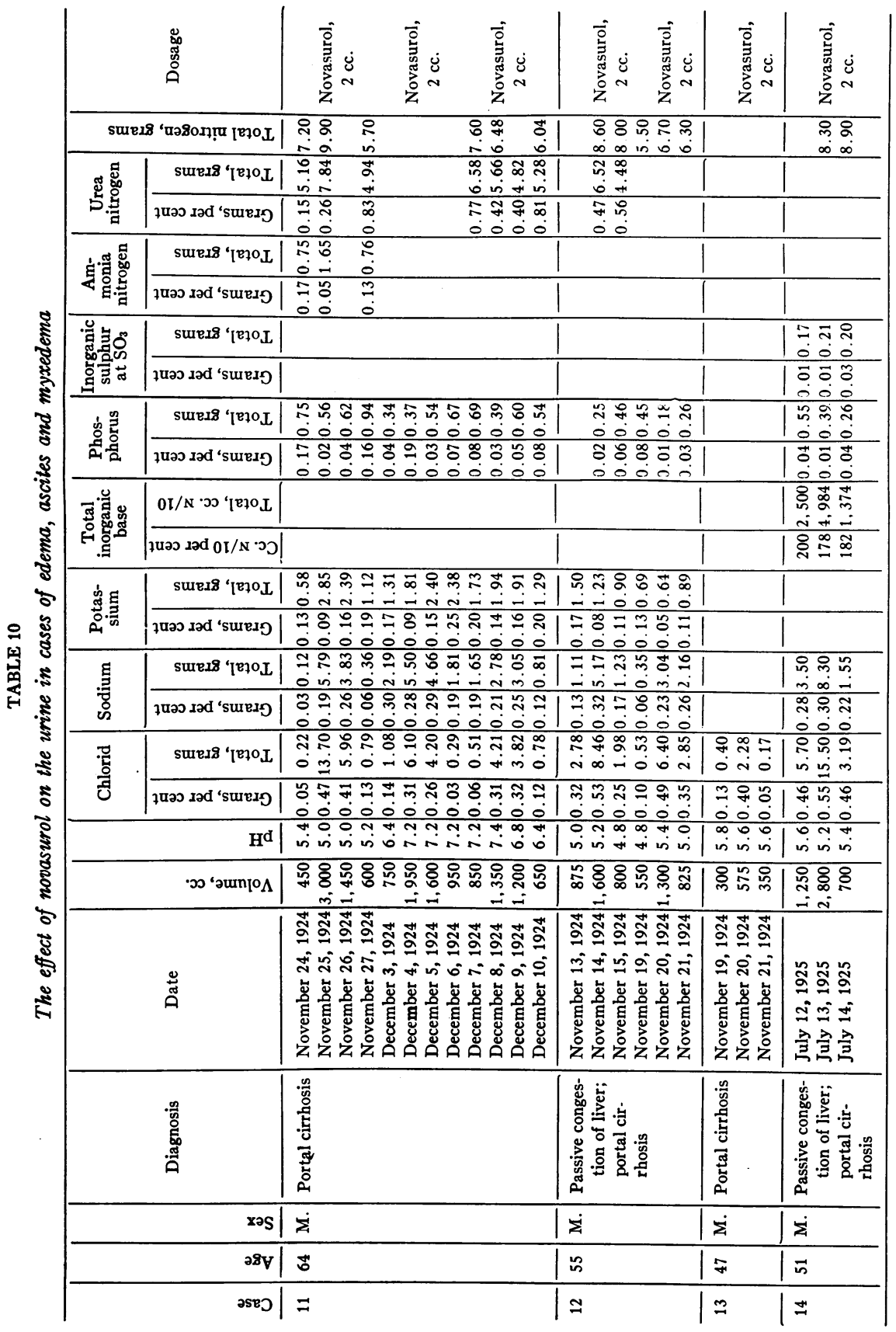




\begin{tabular}{|c|c|c|c|}
\hline 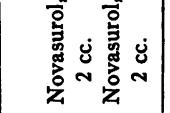 & 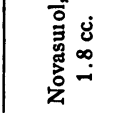 & 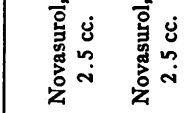 & 迹过 \\
\hline & & & \\
\hline & & & \\
\hline & & & \\
\hline . & & & \\
\hline & & & \\
\hline & & & \\
\hline & & & \\
\hline & & & \\
\hline & & & \\
\hline & & & \\
\hline & & & \\
\hline & & & \\
\hline 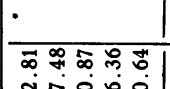 & $80 \%$ & 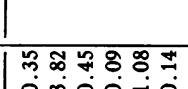 & $8 \%$ \\
\hline 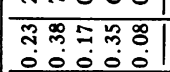 & 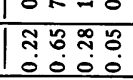 & 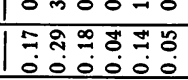 & 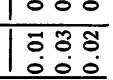 \\
\hline 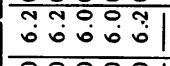 & 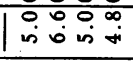 & 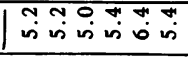 & \\
\hline 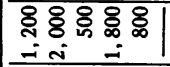 & | & | & |용음월 \\
\hline | & $\mid \begin{array}{l}* \\
0\end{array}$ & & \\
\hline 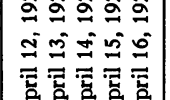 & 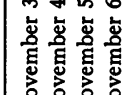 & 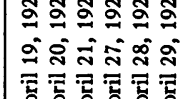 & 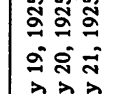 \\
\hline & & & \\
\hline 鄫 & 趈 & 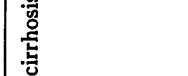 & 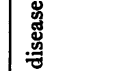 \\
\hline 咅 & 离 & 咅 & 童 \\
\hline$\dot{z}$ & | iि & | is & $1 \dot{z}$ \\
\hline$D$ & 18 & 15 & $\approx$ \\
\hline & 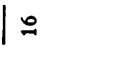 & $=$ & 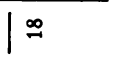 \\
\hline
\end{tabular}




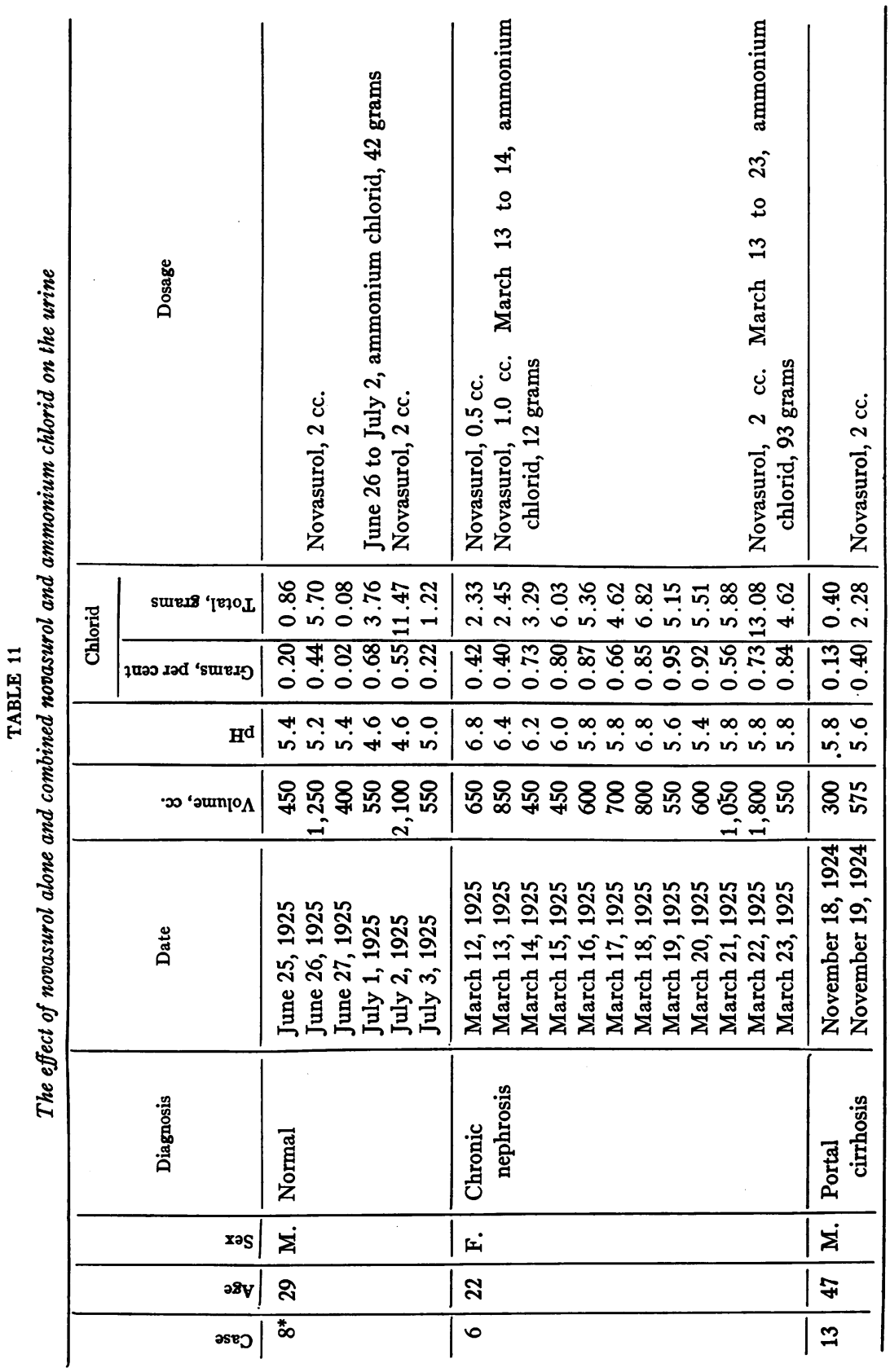




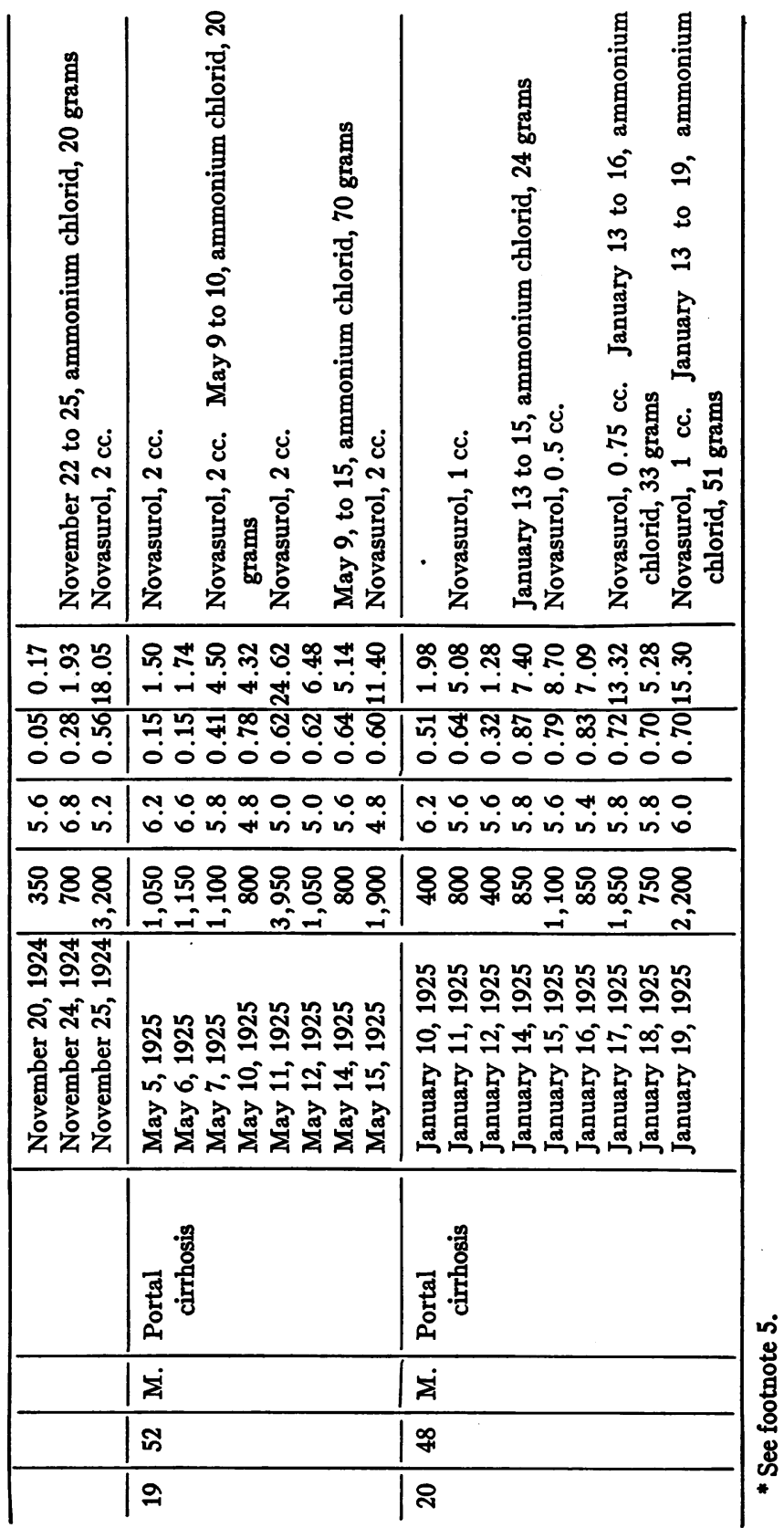


chlorids, sodium and total fixed base, as in the normal control experiments.

\section{COMBINED EFFECTS OF AMMONIUM CHLORID AND ORGANIC MERCURY COMPOUNDS}

By the extensive use of any new therapeutic agent one soon learns to limit its use to certain specific conditions. Ammonium chlorid produced striking diuresis in our early cases of edema. We then

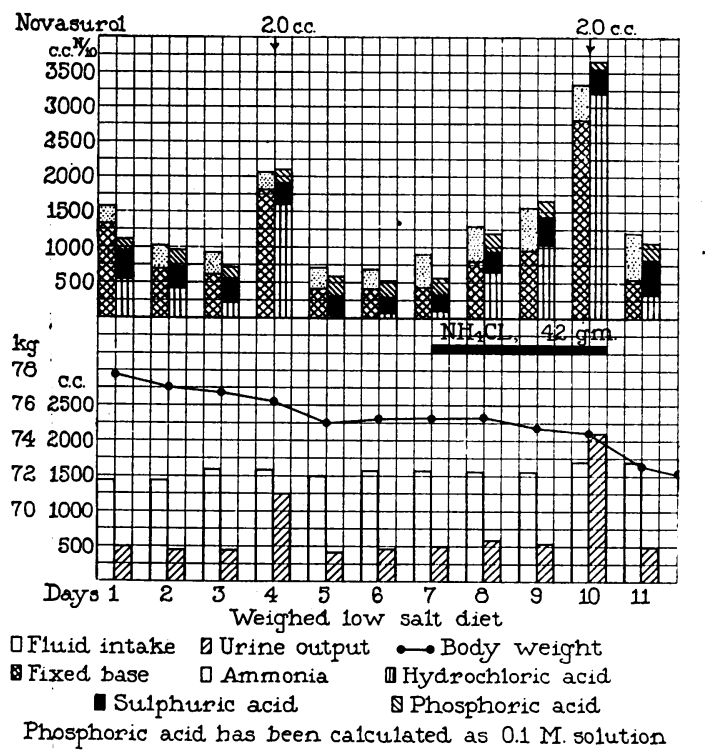

Fig. 2. Relative Diuretic Effect of Novasurol Alone, and Novasurol Plus Ammonium Cholrm; also the Sum of the Inorganic Acm and Inorganic Basic Ions Plus Ammonia in the Urine Calculated as Onetenth Normal Cubic Centimeters, Acm or Alkali. (Case 8, Tables $3,4,9,11,12,13$ AND 14)

began to have cases in which the salt failed to act. Similarly novasurol was, in our first cases, very effective in reducing edema and ascites. Subsequently, it also failed, in certain cases, to produce the desired diuresis. These facts led us to a trial of their combined diuretic effects in cases in which one or the other had previously failed or produced only temporary, slight diuresis. The therapeutic results 
of ammonium chlorid and novasurol in combination has, in many cases, been really remarkable, the loss of weight due to removal of previously retained fluid amounting to as much as 70 pounds $(31.8$ $\mathrm{kgm}$.) in from five to six weeks.

Comparison of the results obtained before and after the use of ammonium chlorid and novasurol combined are well demonstrated in table 11. In the normal control, case 8 , the volume of urine is distinctly greater, $2100 \mathrm{cc}$., after the combined drugs than after novasurol alone, $1250 \mathrm{cc}$. (fig. 2). In case 13 novasurol produced no diuresis on November 19, whereas with the combined drugs the output of urine six days later reached $3200 \mathrm{cc}$.

Such results established the efficacy of this form of treatment on a sound basis. We have since made numerous studies directed chiefly toward elucidating further the problem of the action of these substances. Interesting changes in the acid-base equilibrium, water balance, the concentration of chlorid and other inorganic ions, and in the formation of urea and ammonia have occurred which are of biologic significance and may be useful in throwing light on other allied problems.

Blood. Studies of blood concentration were carried out in detail in case 21 (table 12). The patient received the usual constant diet, low in water and salt ( 3 grams of ammonium chlorid daily as a substitute for sodium chlorid), throughout his stay of five weeks. Novasurol was given on seven days, with marked diuresis (a maximum of $2900 \mathrm{cc}$.). During four of the periods of diuresis the hemoglobin increased in concentration, and in one the plasma protein increased in like manner. The plasma water showed some minor hourly variations which were not constant. The plasma chlorid remained unaltered during one period, but fell distinctly at the end of the twenty-four hours in another. The carbon dioxid combining-power of the plasma deviated from the normal once with a moderate fall. No changes of significance were observed in the concentration of sodium, potassium, calcium and phosphate in the serum. In a normal subject and in a patient with portal cirrhosis, who were receiving 10 grams of ammonium chlorid daily (cases 8 and 22, table 12) the chlorid concentration fell slightly in one but remained constant in the other. 


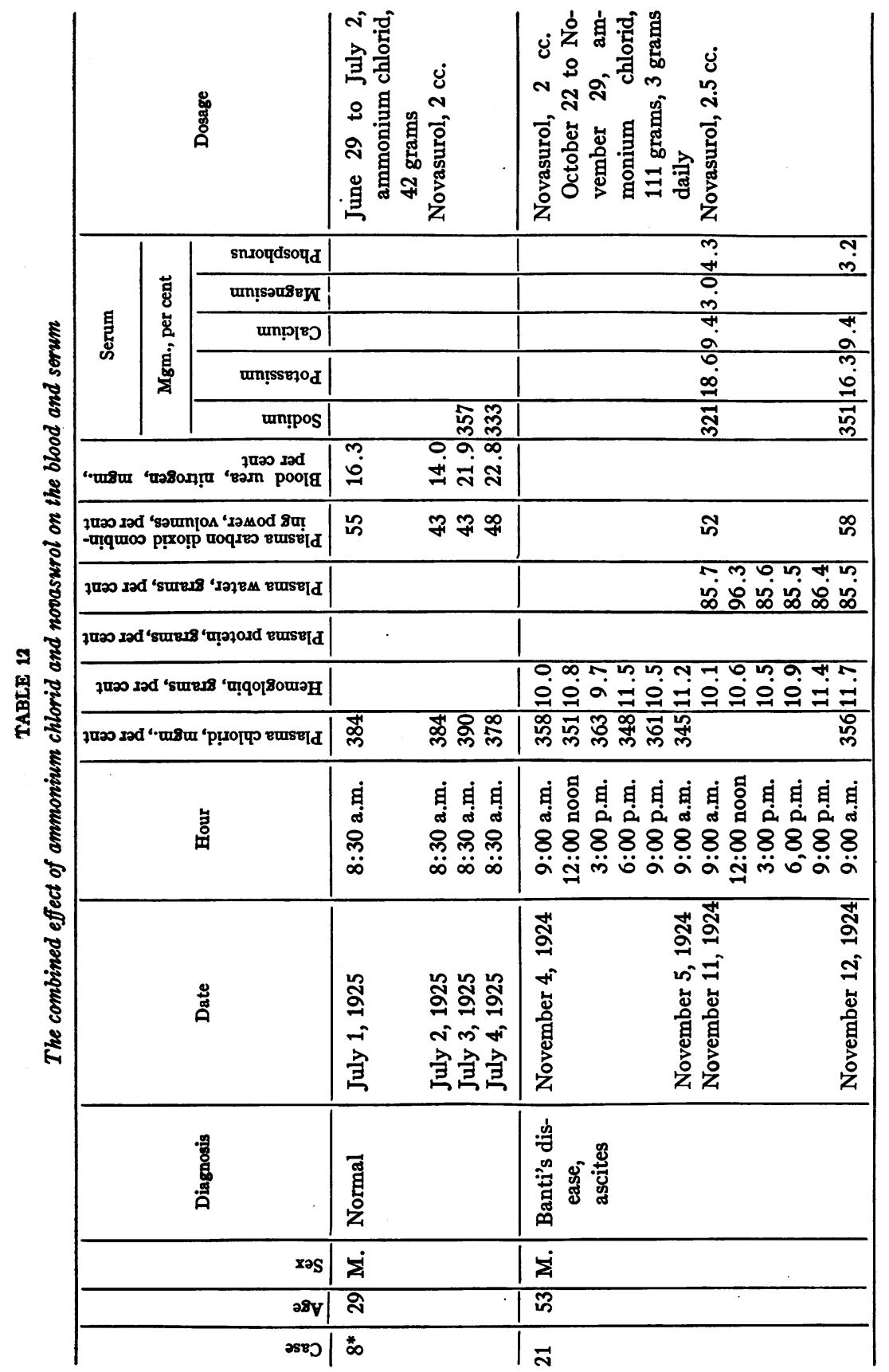




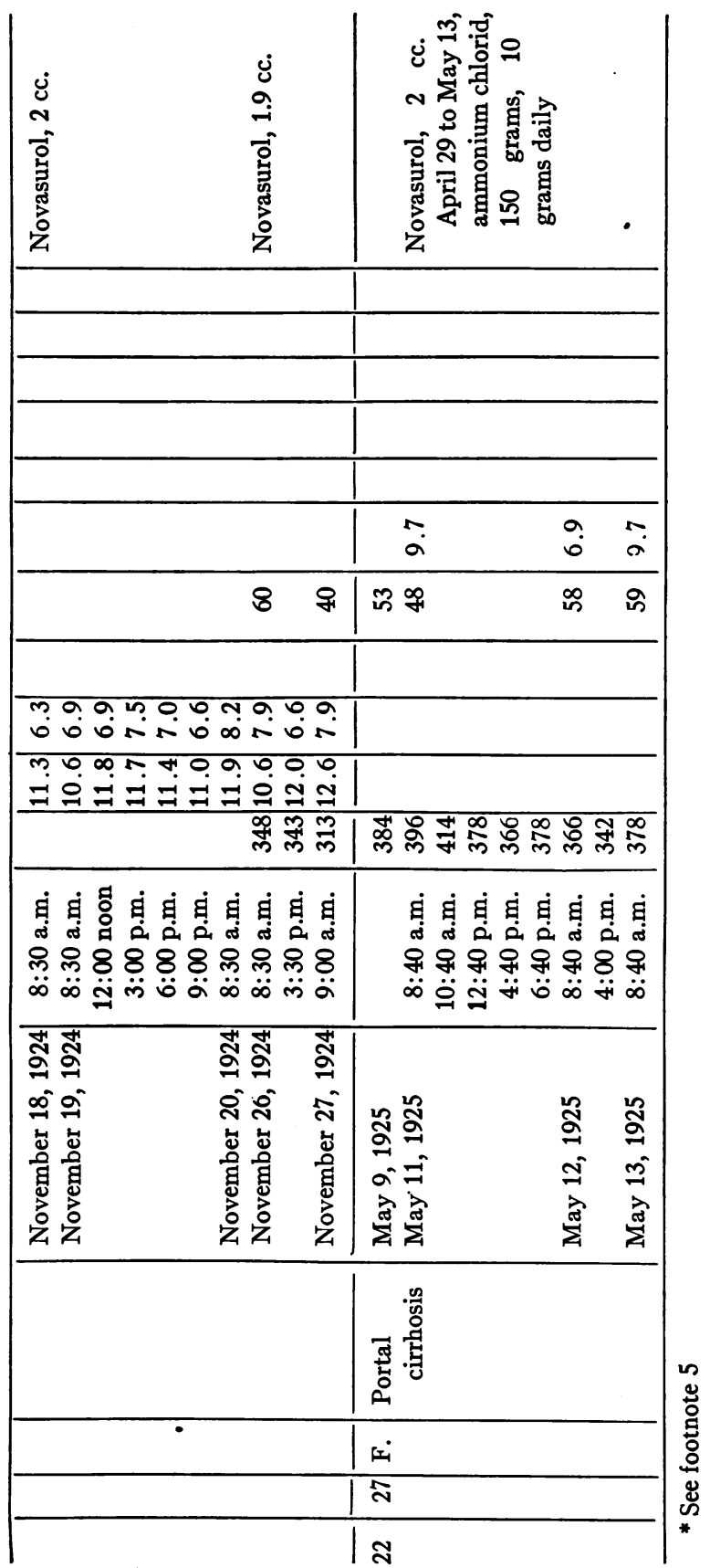




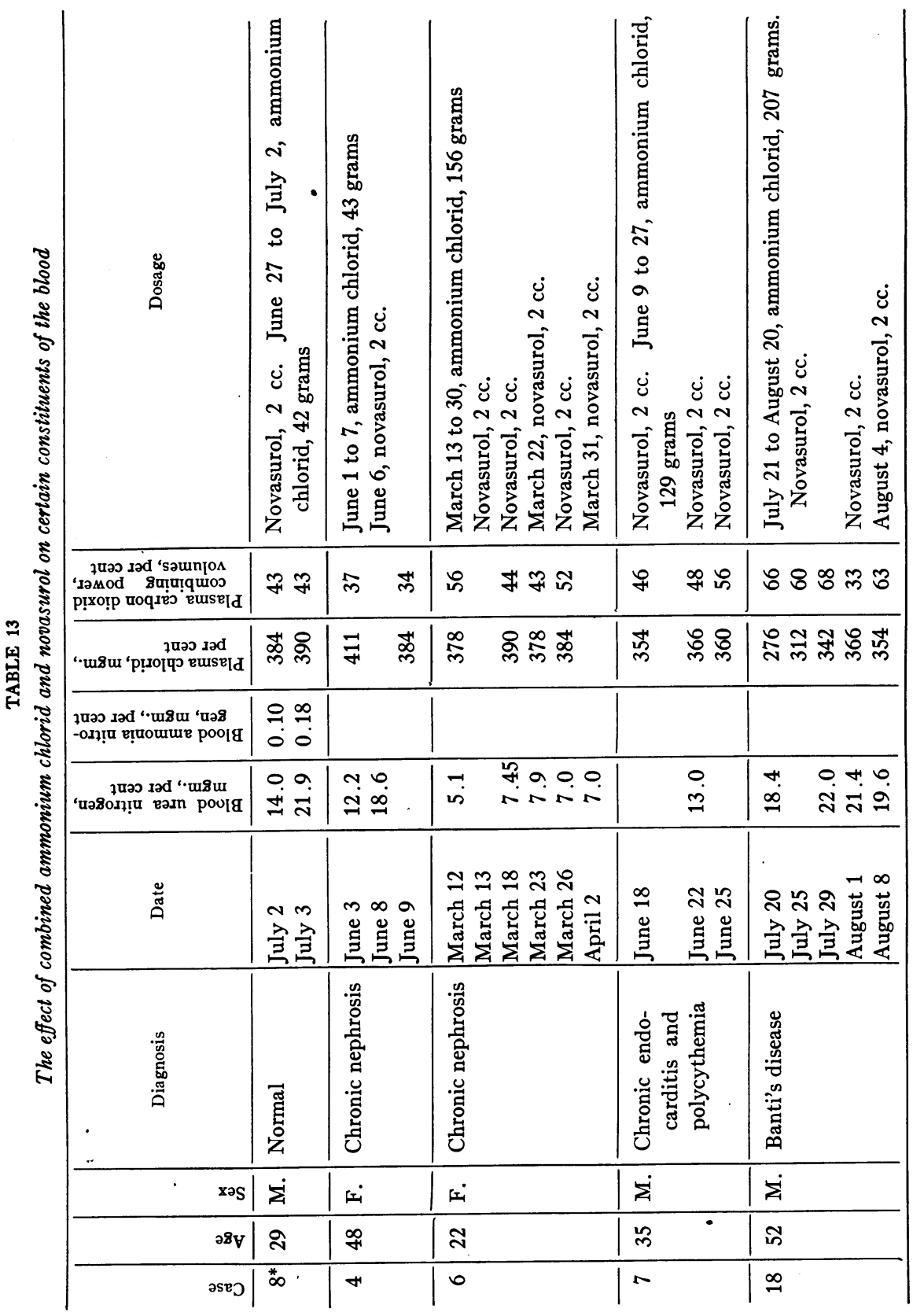




\begin{tabular}{|c|c|c|c|c|c|c|}
\hline 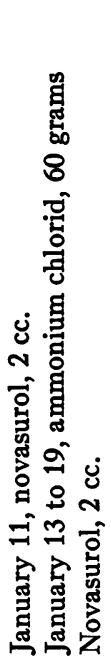 & 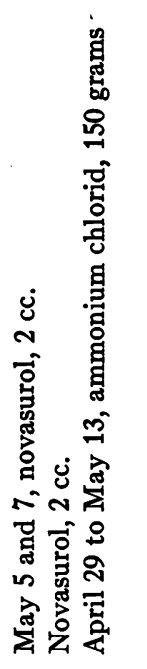 & 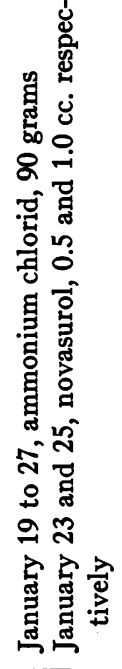 & 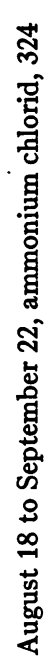 & 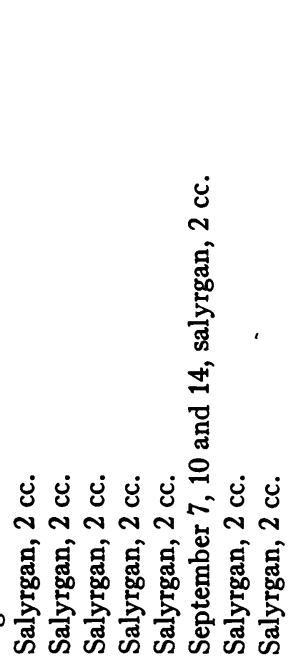 & 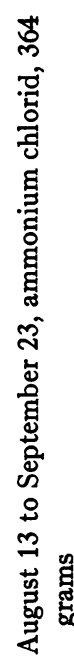 & 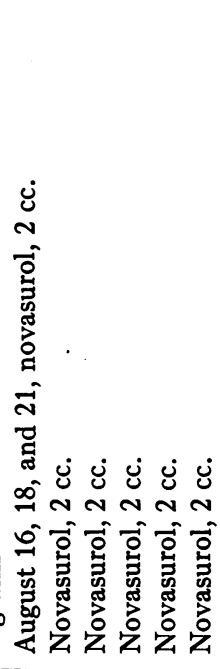 \\
\hline 节尔 & 舫 & 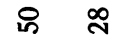 & ㅇ & 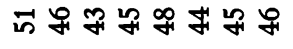 & $\mathscr{8}$ & 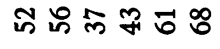 \\
\hline 命鸽草 & 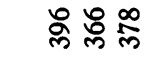 & శ్ల & 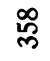 & 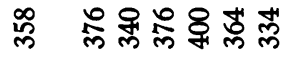 & 8 & 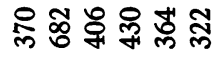 \\
\hline 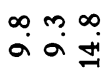 & $\begin{array}{l}\infty \\
0\end{array}$ & ọm & $\stackrel{9}{0}$ & 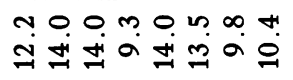 & $\stackrel{0}{0}$ & 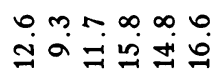 \\
\hline 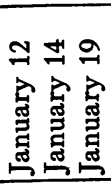 & 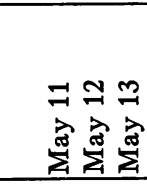 & 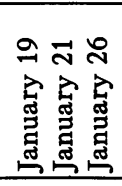 & 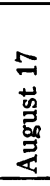 & 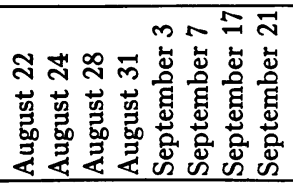 & 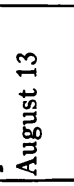 & 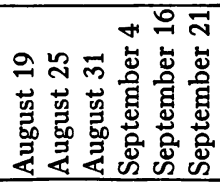 \\
\hline 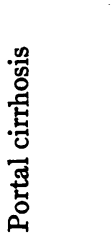 & 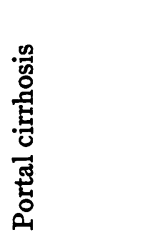 & 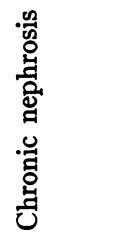 & 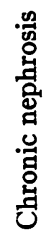 & & 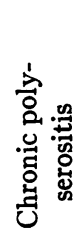 & \\
\hline$\dot{\Sigma}$ & si & Si & $\dot{\Sigma}$ & & $\dot{\Sigma}$ & . \\
\hline$\stackrel{\infty}{+}$ & $\hat{N}$ & กี่ & $\stackrel{\infty}{\sim}$ & & 노 & \\
\hline 오 & ส & $\tilde{n}$ & הే & & น & \\
\hline
\end{tabular}




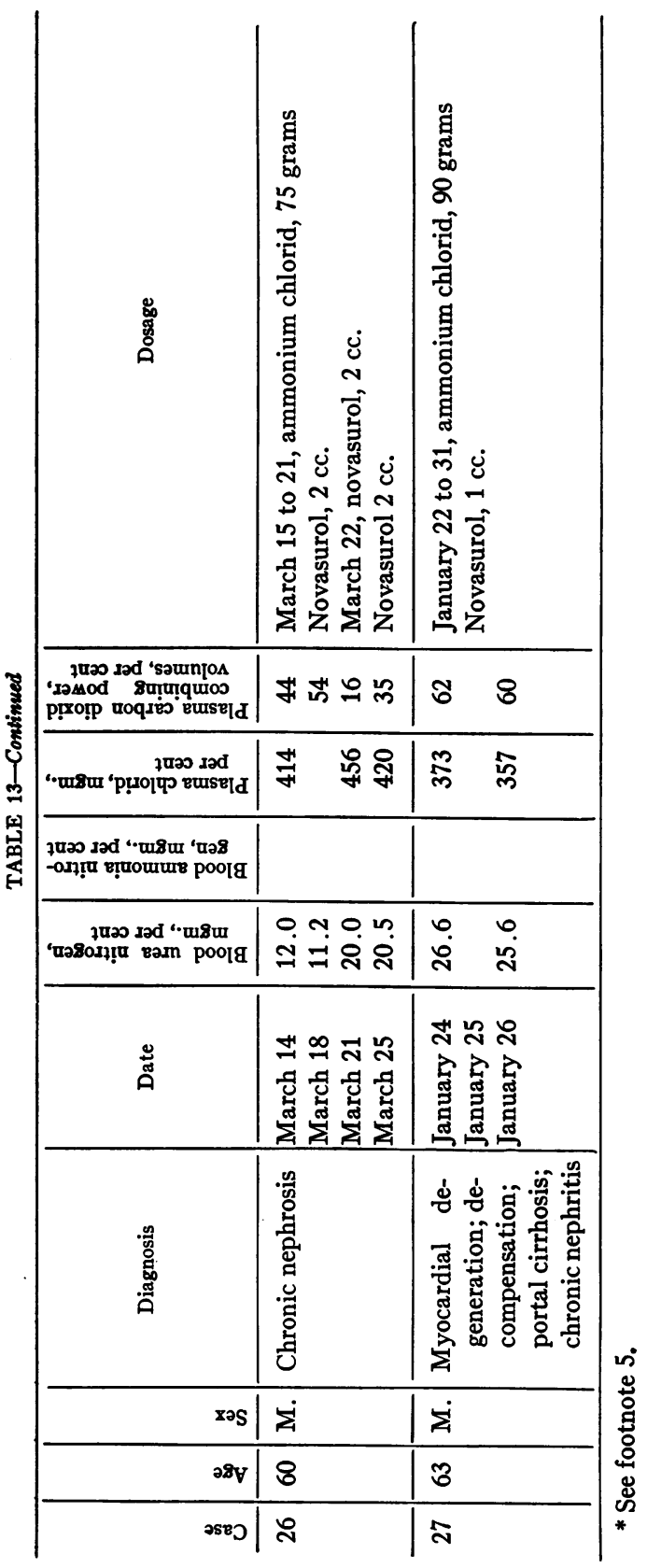


Since ammonium chlorid alone caused a rise in blood-ammonia, blood-urea and plasma-chlorid, and a decrease in carbon dioxid combining-power of the plasma, it was of interest to ascertain what the added effect of novasurol would be. The results of such a combined action are given in table 13. In the normal subject (case 8) there was a rise in ammonia and urea but no fluctuation in either the chlorid or carbon dioxid combining-power, although both of the latter were abnormal, the chlorid being increased above the normal and the carbon dioxid combining-power decreased. The results in cases 4, 18,23 , and 26 , the rise in blood-urea and plasma-chlorid and the fall in carbon dioxid combining-power were identical with those in which ammonium chlorid alone was ingested (table 3). In Cases 24 and 25, there was a moderate rise in blood-urea and chlorid and a moderate early decrease in the carbon dioxid combining-power. With the long-continued administration of both substances (more than a month) these blood values tend to approach the normal. Cases 6 and 22 show that a low content of blood-urea, an increased content of plasma-chlorid, and a normal value for the carbon dioxid combining-power can be maintained after continued large doses of ammonium chlorid and novasurol. Normal values for urea, chlorid and carbon dioxid combining-power were present in cases 21 and 25 (tables 12 and 13) at some time during the combined form of treatment. It is noteworthy that these normal values were found during periods of active diuresis in cases of long-standing marked edema, after long-continued administration of both drugs.

The effectiveness of ammonium chlorid in increasing a subnormal content of plasma-chlorid is well illustrated in case 18 (fig. 6, tables 10,13 and 14). Within eight days the subnormal level of $276 \mathrm{mgm}$. was raised to normal, $342 \mathrm{mgm}$., thus making it possible for novasurol to cause a satisfactory diuresis. Dilute hydrochloric acid was substituted for ammonium chlorid in case 30 (table 15). The patient had portal cirrhosis with ascites. This acid caused a fall in blood urea and only slight changes in plasma chlorid and the carbon dioxid combining-power of the plasma, yet the subsequent administration of salyrgan caused a large increase in the volume of the urine.

Urine. In our experience diuresis was usual, following the satisfactory administration of ammonium chlorid and novasurol. The 
TAB

The effect of combined ammonium

\begin{tabular}{|c|c|c|c|c|c|c|c|c|c|c|c|c|c|c|c|c|c|}
\hline \multirow[b]{2}{*}{ ఝू } & \multirow[b]{2}{*}{$\underset{8}{8}$} & \multirow[b]{2}{*}{ 㟧 } & \multirow[b]{2}{*}{ Diagnosis } & \multirow[b]{2}{*}{ Date, 1925} & \multicolumn{3}{|c|}{ Blood } & \multirow[b]{2}{*}{$\begin{array}{l}8 \\
\dot{8} \\
\text { Ė } \\
0 \\
0\end{array}$} & \multirow[b]{2}{*}{ 至 } & \multicolumn{2}{|c|}{ Chlorid } & \multicolumn{2}{|c|}{ Sodium } & \multicolumn{2}{|c|}{$\begin{array}{l}\text { Potas- } \\
\text { sium }\end{array}$} & \multicolumn{2}{|c|}{ Calcium } \\
\hline & & & & & 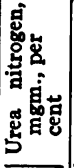 & 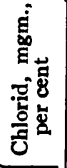 & 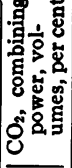 & & & 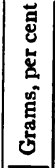 & 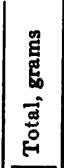 & 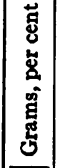 & 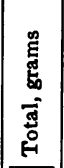 & 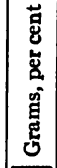 & 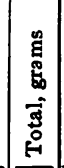 & 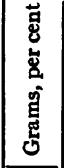 & $\begin{array}{l}\text { है } \\
\text { है } \\
\text { है } \\
\text { हैं } \\
\text { से }\end{array}$ \\
\hline $8 *$ & 29 & M. & Normal & $\begin{array}{l}\text { July } 1 \\
\text { July } 2 \\
\text { July } 3\end{array}$ & $\begin{array}{l}16.0 \\
14.0 \\
21.6 \\
\end{array}$ & $\begin{array}{l}384 \\
384 \\
390 \\
\end{array}$ & $\begin{array}{l}55 \\
43 \\
43 \\
\end{array}$ & $\begin{array}{r}550 \\
2,100 \\
500 \\
\end{array}$ & $\begin{array}{l}4.6 \\
4.6 \\
5.0 \\
\end{array}$ & $\begin{array}{l}0.68 \\
0.55 \\
0.22 \\
\end{array}$ & $\begin{array}{r}3.76 \\
11.47 \\
1.22 \\
\end{array}$ & $\begin{array}{l}0.03 \\
0.20 \\
0.03 \\
\end{array}$ & $\begin{array}{l}0.15 \\
4.15 \\
0.20 \\
\end{array}$ & $\begin{array}{l}0.49 \\
0.13 \\
0.24 \\
\end{array}$ & $\begin{array}{l}2.70 \\
2.84 \\
1.33 \\
\end{array}$ & $\begin{array}{l}0.03 \\
0.01 \\
0.02 \\
\end{array}$ & $\begin{array}{l}0.19 \\
0.30 \\
0.11\end{array}$ \\
\hline 4 & 48 & F. & Chronic nephrosis & $\begin{array}{l}\text { June } 4 \\
\text { June } 5 \\
\text { June } 6 \\
\text { June } 7\end{array}$ & 12.0 & 411 & 37 & $\begin{array}{r}900 \\
1,200 \\
3,100 \\
1,050 \\
\end{array}$ & $\begin{array}{l}6.0 \\
5.2 \\
5.6 \\
5.4 \\
\end{array}$ & $\mid \begin{array}{l}0.46 \\
0.35 \\
0.52 \\
0.53\end{array}$ & $\begin{array}{r}4.08 \\
4.25 \\
16.00 \\
5.61 \\
\end{array}$ & $\begin{array}{l}0.14 \\
0.13 \\
0.28 \\
0.26\end{array}$ & $\begin{array}{l}1.23 \\
1.50 \\
8.68 \\
2.70 \\
\end{array}$ & $\begin{array}{l}0.12 \\
0.14 \\
0.06 \\
0.10\end{array}$ & \begin{tabular}{|l|}
1.03 \\
1.63 \\
1.76 \\
1.06 \\
\end{tabular} & $\begin{array}{l}0.003 \\
0.003 \\
0.004 \\
0.006 \\
\end{array}$ & $\begin{array}{l}0.02 \\
0.04 \\
0.13 \\
0.06\end{array}$ \\
\hline 7 & 35 & M. & $\begin{array}{l}\text { Chronic encar- } \\
\text { ditis, polycy- } \\
\text { themia }\end{array}$ & $\begin{array}{l}\text { June } 21 \\
\text { June } 22 \\
\text { June } 23 \\
\text { June } 24\end{array}$ & 13.0 & 366 & 48 & $\begin{array}{r}300 \\
1,750 \\
2,050 \\
1,000 \\
\end{array}$ & $\begin{array}{l}5.2 \\
5.2 \\
4.8 \\
5.6 \\
\end{array}$ & $\mid \begin{array}{l}0.38 \\
0.56 \\
0.56 \\
0.51 \\
\end{array}$ & $\begin{array}{r}1.15 \\
9.27 \\
11.44 \\
5.04 \\
\end{array}$ & & & & & & \\
\hline 18 & 52 & M. & $\begin{array}{l}\text { Banti's disease, } \\
\text { ascites }\end{array}$ & \begin{tabular}{|l} 
July 31 \\
August 1 \\
August 2 \\
August 3 \\
August 4 \\
August 5 \\
August 6 \\
\end{tabular} & $\begin{array}{l}21.6 \\
21.0 \\
17.0\end{array}$ & 372 & 46 & $\begin{array}{r}700 \\
2,650 \\
2,200 \\
1,300 \\
3,175 \\
1,150 \\
950 \\
\end{array}$ & $\begin{array}{l}5.6 \\
6.6 \\
6.2 \\
6.4 \\
6.4 \\
6.2 \\
5.6 \\
\end{array}$ & $\mid \begin{array}{l}0.16 \\
0.43 \\
0.40 \\
0.38 \\
0.41 \\
0.36 \\
0.13 \\
\end{array}$ & $\begin{array}{r}1.13 \\
11.45 \\
8.70 \\
4.98 \\
12.90 \\
4.14 \\
1.55 \\
\end{array}$ & $\begin{array}{l}0.13 \\
0.13 \\
0.10 \\
0.18 \\
0.15 \\
0.05 \\
0.03 \\
\end{array}$ & $\begin{array}{l}0.94 \\
3.44 \\
2.31 \\
2.29 \\
4.73 \\
0.53 \\
0.33 \\
\end{array}$ & $\begin{array}{l}0.17 \\
0.17 \\
0.15 \\
0.09 \\
0.09 \\
0.07 \\
0.05 \\
\end{array}$ & $\begin{array}{l}1.16 \\
4.51 \\
3.23 \\
1.17 \\
2.86 \\
0.85 \\
0.47 \\
\end{array}$ & . & \\
\hline 20 & 48 & M. & Portal cirrhosis & $\begin{array}{l}\text { January } 18 \\
\text { January } 19 \\
\text { August } 15 \\
\end{array}$ & 14.3 & 404 & 36 & $\begin{array}{r}750 \\
2,200 \\
850 \\
\end{array}$ & $\begin{array}{l}5.8 \\
6.0 \\
4.6 \\
\end{array}$ & \begin{tabular}{|}
0.70 \\
0.70 \\
0.52 \\
\end{tabular} & $\begin{array}{r}5.28 \\
15.30 \\
4.34 \\
\end{array}$ & $\begin{array}{l}0.34 \\
0.39 \\
\end{array}$ & $\begin{array}{l}2.53 \\
8.62\end{array}$ & $\begin{array}{l}0.15 \\
0.08\end{array}$ & $\begin{array}{l}1.09 \\
1.80\end{array}$ & $\begin{array}{l}0.03 \\
0.02\end{array}$ & $\begin{array}{l}0.25 \\
0.37\end{array}$ \\
\hline 22 & 27 & F. & Portal cirrhosis & $\begin{array}{l}\text { May } 10 \\
\text { May } 11 \\
\text { May } 12 \\
\end{array}$ & $\begin{array}{l}9.7 \\
6.9 \\
\end{array}$ & $\begin{array}{l}396 \\
366 \\
\end{array}$ & $\begin{array}{l}48 \\
58 \\
\end{array}$ & $\begin{array}{r}850 \\
3,700 \\
1,550 \\
\end{array}$ & $\begin{array}{l}5.6 \\
5.0 \\
5.4 \\
\end{array}$ & $\begin{array}{l}0.66 \\
0.64 \\
0.56 \\
\end{array}$ & $\begin{array}{r}5.64 \\
23.76 \\
8.82 \\
\end{array}$ & $\begin{array}{l}0.13 \\
0.30 \\
0.21 \\
\end{array}$ & $\begin{array}{r}1.10 \\
11.19 \\
3.27 \\
\end{array}$ & $\begin{array}{l}0.08 \\
0.06 \\
0.10\end{array}$ & $\begin{array}{l}1.11 \\
2.05 \\
1.50\end{array}$ & $\begin{array}{l}0.03 \\
0.02 \\
0.01 \\
\end{array}$ & $\begin{array}{l}0.42 \\
0.59 \\
0.24 \\
\end{array}$ \\
\hline 24 & 18 & M. & Chronic nephrosis & $\begin{array}{l}\text { September } 2 \\
\text { September } 3 \\
\text { September } 4 \\
\end{array}$ & 14.0 & 376 & 48 & $\begin{array}{r}500 \\
3,700 \\
550 \\
\end{array}$ & $\begin{array}{l}5.6 \\
5.4 \\
5.6 \\
\end{array}$ & $\begin{array}{l}0.69 \\
0.53 \\
0.48 \\
\end{array}$ & $\begin{array}{r}3.39 \\
19.50 \\
2.64 \\
\end{array}$ & $\begin{array}{l}0.01 \\
0.20 \\
0.02 \\
\end{array}$ & $\begin{array}{l}0.05 \\
7.55 \\
0.14 \\
\end{array}$ & $\begin{array}{l}0.21 \\
0.08 \\
0.10\end{array}$ & $\begin{array}{l}1.05 \\
3.15 \\
0.57 \\
\end{array}$ & & \\
\hline 25 & 26 & M. & Polyserositis & \begin{tabular}{|l|} 
August 16 \\
\\
\multicolumn{1}{c|}{ Total } \\
August 17 \\
August 18 \\
August 19 \\
September 27 \\
September 28 \\
September 29 \\
September 30 \\
October 1 \\
\end{tabular} & 18.0 & $\begin{array}{l}370 \\
322\end{array}$ & $\begin{array}{l}52 \\
68\end{array}$ & $\left|\begin{array}{r}1,700 \\
2,025 \\
1,950 \\
5,675 \\
700 \\
5,710 \\
715 \\
700 \\
600 \\
500 \\
400\end{array}\right|$ & $\begin{array}{l}6.4 \\
5.4 \\
7.2 \\
5.4 \\
5.4 \\
5.0 \\
5.4 \\
5.8 \\
5.2 \\
5.6\end{array}$ & $\left|\begin{array}{l}0.61 \\
0.56 \\
0.56 \\
0.51 \\
0.53 \\
0.47 \\
0.17 \\
0.16 \\
0.26 \\
0.29\end{array}\right|$ & $\begin{array}{r}10.40 \\
11.42 \\
10.99 \\
32.81 \\
3.57 \\
30.49 \\
3.34 \\
1.19 \\
0.97 \\
1.32 \\
1.15\end{array}$ & $\begin{array}{l}0.38 \\
0.35 \\
0.40 \\
0.03 \\
0.24 \\
0.04 \\
0.02 \\
0.01 \\
0.02 \\
0.02\end{array}$ & $\begin{array}{r}6.43 \\
7.09 \\
7.76 \\
21.28 \\
0.20 \\
11.28 \\
0.25 \\
0.13 \\
0.05 \\
\\
0.11 \\
0.08\end{array}$ & $\begin{array}{l}0.03 \\
0.01 \\
0.01 \\
0.12 \\
0.10 \\
0.06\end{array}$ & $\left|\begin{array}{l}0.58 \\
0.23 \\
0.25 \\
1.06 \\
0.91 \\
4.75 \\
0.38\end{array}\right|$ & $\begin{array}{r}0.005 \\
0.004 \\
0.004 \\
.\end{array}$ & $\begin{array}{l}0.08 \\
0.08 \\
0.09 \\
0.25\end{array}$ \\
\hline 26 & 60 & M. & Chronic nephrosis & $\begin{array}{l}\text { March 24 } \\
\text { March 25 } \\
\text { March 26 } \\
\end{array}$ & 20.0 & 420 & 35 & $\begin{array}{r}750 \\
2,800 \\
1,300 \\
\end{array}$ & $\begin{array}{l}5.4 \\
5.4 \\
7.0 \\
\end{array}$ & $\begin{array}{l}0.51 \\
0.46 \\
\end{array}$ & $\begin{array}{r}2.52 \\
14.88 \\
5.94 \\
\end{array}$ & $\begin{array}{l}0.11 \\
0.28 \\
0.27 \\
\end{array}$ & $\begin{array}{l}0.84 \\
7.84 \\
3.52 \\
\end{array}$ & $\begin{array}{l}0.09 \\
0.03 \\
0.04 \\
\end{array}$ & $\begin{array}{l}0.65 \\
0.76 \\
0.58 \\
\end{array}$ & & \\
\hline 27 & 63 & M. & $\begin{array}{l}\text { Chronic myocar- } \\
\text { dial degenera- } \\
\text { tion; chronic } \\
\text { nephritis; por- } \\
\text { tal cirrhosis } \\
\end{array}$ & $\begin{array}{l}\text { January } 24 \\
\text { January } 25 \\
\text { January } 26\end{array}$ & 24.4 & 373 & 60 & $\left|\begin{array}{l}1,350 \\
2,850 \\
1,650\end{array}\right|$ & $\begin{array}{l}4.6 \\
4.4 \\
4.6\end{array}$ & $\left|\begin{array}{l}0.66 \\
0.66 \\
0.46\end{array}\right|$ & $\begin{array}{r}9.24 \\
19.50 \\
7.50\end{array}$ & $\left|\begin{array}{l}0.39 \\
0.44 \\
0.29\end{array}\right|$ & $\begin{array}{r}5.92 \\
12.68 \\
4.62\end{array}$ & $\left|\begin{array}{l}0.13 \\
0.07 \\
0.10\end{array}\right|$ & $\left|\begin{array}{l}1.74 \\
2.05 \\
1.60\end{array}\right|$ & $\begin{array}{l}0.18 \\
0.18 \\
0.13\end{array}$ & $\begin{array}{l}0.24 \\
0.52 \\
0.22\end{array}$ \\
\hline 29 & 20 & F. & Polyserositis & $\begin{array}{l}\text { March } 1 \\
\text { March } 2 \\
\text { March } 3\end{array}$ & 12.0 & 402 & 48 & $\begin{array}{r}300 \\
2,400 \\
400\end{array} \mid$ & $\begin{array}{l}6.4 \\
6.2 \\
6.0\end{array}$ & $\left|\begin{array}{l}0.64 \\
0.58\end{array}\right|$ & $\begin{array}{r}1.94 \\
15.26 \\
2.30\end{array}$ & $\left|\begin{array}{l}0.07 \\
0.30 \\
0.06\end{array}\right|$ & $\begin{array}{l}0.22 \\
7.32 \\
0.25\end{array}$ & $\mid \begin{array}{l}0.12 \\
0.07 \\
0.11\end{array}$ & $\left|\begin{array}{l}0.37 \\
1.64 \\
0.46\end{array}\right|$ & $\left|\begin{array}{l}0.005 \\
0.001 \\
0.003\end{array}\right|$ & $\mid \begin{array}{l}0.01 \\
0.27 \\
0.01\end{array}$ \\
\hline
\end{tabular}

- See footnote 5 .

$\uparrow$ Full diet not taken. 
LE 14

chlorid and novasurol on blood and urine

\begin{tabular}{|c|c|c|c|c|c|c|c|c|c|c|c|c|c|c|c|}
\hline \multicolumn{2}{|c|}{ Magnesium } & \multicolumn{2}{|c|}{$\begin{array}{l}\text { Phos- } \\
\text { phorus }\end{array}$} & \multicolumn{2}{|c|}{$\begin{array}{c}\text { Inorganic } \\
\text { sulphur } \\
\text { as } \mathrm{SO}_{2}\end{array}$} & \multicolumn{2}{|c|}{$\begin{array}{l}\text { Total inor- } \\
\text { ganic base }\end{array}$} & \multicolumn{2}{|c|}{$\underset{\text { monia }}{\text { Am- }}$} & \multicolumn{2}{|c|}{$\begin{array}{c}\text { Urea } \\
\text { nitrogen }\end{array}$} & \multirow{2}{*}{ 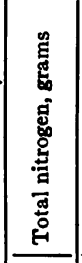 } & \multirow{2}{*}{ 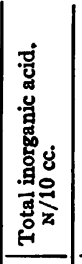 } & \multirow{2}{*}{ 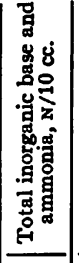 } & \multirow[b]{2}{*}{ Dosage } \\
\hline 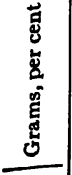 & 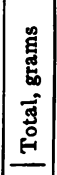 & 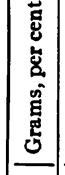 & 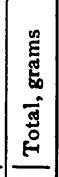 & 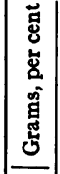 & 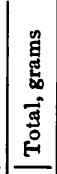 & 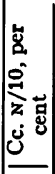 & 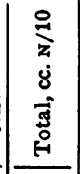 & 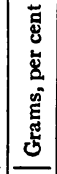 & 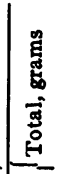 & 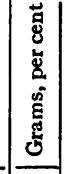 & 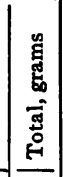 & & & & \\
\hline $\begin{array}{l}0.02 \\
0.01 \\
0.02 \\
\end{array}$ & $\begin{array}{l}0.11 \\
0.19 \\
0.11 \\
\end{array}$ & $\begin{array}{l}0.14 \\
0.02 \\
0.15\end{array}$ & $\begin{array}{l}0.77 \\
0.46 \\
0.85 \\
\end{array}$ & $\begin{array}{l}0.21 \\
0.05 \\
0.33 \\
\end{array}$ & $\begin{array}{l}1.16 \\
1.83 \\
\end{array}$ & $\begin{array}{l}172 \\
133 \\
100 \\
\end{array}$ & $\begin{array}{r}946 \\
2,793 \\
550 \\
\end{array}$ & $\begin{array}{l}0.16 \\
0.03 \\
0.17 \\
\end{array}$ & \begin{tabular}{l|l|l|}
6.88 \\
0.73 \\
0.96 \\
\end{tabular} & \begin{tabular}{|l|l|} 
& 1.44 \\
0.35 \\
1.52 \\
\end{tabular} & $\begin{array}{l}8.90 \\
7.25 \\
8.36 \\
\end{array}$ & $\begin{array}{l}11.00 \\
9.90 \\
10.00 \\
\end{array}$ & $\begin{array}{l}2,200 \\
3,869 \\
1,603 \\
\end{array}$ & $\begin{array}{l}1,576 \\
3,317 \\
1,232 \\
\end{array}$ & $\begin{array}{l}\text { June } 29 \text { to July 2, ammonium } \\
\text { chlorid, } 42 \text { grams } \\
\text { Novasurol, } 2 \text { cc. }\end{array}$ \\
\hline $\begin{array}{l}0.007 \\
0.005 \\
0.003 \\
0.004 \\
\end{array}$ & $\begin{array}{l}0.06 \\
0.05 \\
0.10 \\
0.04 \\
\end{array}$ & $\begin{array}{l}0.04 \\
0.04 \\
0.01 \\
0.04 \\
\end{array}$ & $\begin{array}{l}0.38 \\
0.54 \\
0.46 \\
0.42 \\
\end{array}$ & $\begin{array}{l}0.03 \\
0.04 \\
0.03 \\
0.03 \\
\end{array}$ & $\begin{array}{l}0.30 \\
0.44 \\
0.84 \\
0.32 \\
\end{array}$ & $\begin{array}{r}83 \\
88 \\
139 \\
139 \\
\end{array}$ & $\begin{array}{r}757 \\
1,056 \\
4,309 \\
1,460 \\
\end{array}$ & $\begin{array}{l}0.11 \\
0.05 \\
0.03 \\
0.06\end{array}$ & $\begin{array}{l}1.00 \\
0.55 \\
0.84 \\
0.68\end{array}$ & $\begin{array}{l}0.26 \\
0.33 \\
0.19 \\
0.27 \\
\end{array}$ & $\begin{array}{l}2.36 \\
3.92 \\
5.80 \\
2.84 \\
\end{array}$ & $\begin{array}{l}5.10 t \\
6.90 \\
7.00 \\
5.40 t \\
\end{array}$ & $\begin{array}{l}1,591 \\
1,835 \\
5,159 \\
2,069 \\
\end{array}$ & $\begin{array}{l}1,465 \\
1,695 \\
4,815 \\
2,209 \\
\end{array}$ & $\begin{array}{l}\text { June } 1 \text { to } 7 \text {, ammonium chlorid, } 43 \\
\text { grams } \\
\text { Novasurol, } 2 \text { cc. }\end{array}$ \\
\hline$\vec{\nabla}$ & & $\begin{array}{l}0.11 \\
0.02 \\
0.03 \\
0.08 \\
\end{array}$ & $\begin{array}{l}0.33 \\
0.35 \\
0.68 \\
0.80 \\
\end{array}$ & $\begin{array}{l}0.04 \\
0.05 \\
0.08 \\
\end{array}$ & $\begin{array}{l}0.39 \\
0.66 \\
1.05 \\
0.82 \\
\end{array}$ & $\begin{array}{l}160 \\
162 \\
143 \\
\end{array}$ & $\begin{array}{r}405 \\
2,800 \\
3,321 \\
1,430 \\
\end{array}$ & $\begin{array}{l}0.17 \\
0.05 \\
0.05 \\
0.11 \\
\end{array}$ & $\begin{array}{l}0.52 \\
0.95 \\
1.07 \\
1.09 \\
\end{array}$ & & & & $\begin{array}{c}655 \\
3,043 \\
3,981 \\
2,213 \\
\end{array}$ & $\begin{array}{r}776 \\
3,478 \\
4,085 \\
2,208 \\
\end{array}$ & $\begin{array}{l}\text { June } 9 \text { to } 27 \text {, ammonium chlorid, } 129 \\
\text { grams } \\
\text { Novasurol, } 2 \mathrm{cc} .\end{array}$ \\
\hline & l. & $\bullet$ & & & & & & & & & & & & & $\begin{array}{l}\text { July } 21 \text { to August } 20 \text {, ammonium } \\
\text { chlorid, } 207 \text { grams } \\
\text { Novasurol, } 2 \text { cc. } \\
\text { Novasurol, } 2 \text { cc. }\end{array}$ \\
\hline $\begin{array}{l}0.01 \\
0.01\end{array}$ & 0.07 & 0.09 & $\begin{array}{l}0.67 \\
0.18\end{array}$ & & & $\begin{array}{l}209 \\
200\end{array}$ & $\begin{array}{l}1,567 \ddagger \\
1,401\end{array}$ & & & & & & & & $\begin{array}{l}\text { January } 12 \text { to } 20 \text {, ammonium chlorid, } \\
78 \text { grams } \\
\text { Novasurol, } 1 \mathrm{cc} \text {. }\end{array}$ \\
\hline $\begin{array}{l}0.009 \\
0.006 \\
0.006 \\
\end{array}$ & $\begin{array}{l}0.08 \\
0.21 \\
0.09\end{array}$ & 0.06 & $\begin{array}{l}0.51 \\
0.52 \\
0.57 \\
\end{array}$ & & & \begin{tabular}{l|}
122 \\
158 \\
129 \\
\end{tabular} & $\begin{array}{l}1,040+ \\
5,870 \\
1,998\end{array}$ & $\begin{array}{l}0.15 \\
0.05 \\
0.09\end{array}$ & $\begin{array}{l}1.31 \\
1.91 \\
1.38\end{array}$ & $\begin{array}{l}0.52 \\
0.15 \\
0.34\end{array}$ & $\begin{array}{l}4.44 \\
5.51 \\
5.21 \\
\end{array}$ & $\begin{array}{l}7.60 \\
8.50 \\
8.20 \\
\end{array}$ & & $\begin{array}{l}1,133 \\
6,006 \\
2,097 \\
\end{array}$ & $\begin{array}{l}\text { April } 29 \text { to May 13, ammonium } \\
\text { chlorid, } 150 \text { grams } \\
\text { Novasurol, } 1.5 \mathrm{cc} .\end{array}$ \\
\hline & & $\left|\begin{array}{l}0.09 \\
0.01 \\
0.11\end{array}\right| 0$ & $\begin{array}{l}0.47 \\
0.52 \\
0.60\end{array}$ & $\left|\begin{array}{l}0.14 \\
0.02 \\
0.16\end{array}\right|$ & $\begin{array}{l}0.85 \\
0.90 \\
\end{array}$ & $\begin{array}{r}67 \\
130 \\
70 \\
\end{array}$ & $\begin{array}{r}335 \\
4,810 \\
385 \\
\end{array}$ & $\begin{array}{l}0.25 \\
0.04 \\
0.26 \\
\end{array}$ & $\begin{array}{l}1.26 \\
1.63 \\
1.45 \\
\end{array}$ & & & & $\begin{array}{l}1,467 \\
6,075 \\
1,396 \\
\end{array}$ & $\begin{array}{l}1,235 \\
5,975 \\
1,430 \\
\end{array}$ & $\begin{array}{l}\text { August } 19 \text { to September } 30 \text {, am- } \\
\text { monium chlorid, } 384 \text { grams } \\
\text { Salyrgan, } 2 \text { cc. }\end{array}$ \\
\hline & & & & & & & & & & & & & & & $\begin{array}{l}\text { August } 13 \text { to September } 22 \text {, am- } \\
\text { monium chlorid, } 364 \text { grams } \\
\text { August } 15, \text { novasurol, } 2 \text { cc. }\end{array}$ \\
\hline
\end{tabular}

$\begin{array}{llllll}0.04 & 0.33 & 0.14 & 1.08\end{array}$ $\begin{array}{lllllll}0.01 & 0.39 & 0.02 & 1.18\end{array}$ $\begin{array}{llllllll}0.09 & 0.58 & 0.11 & 0.67\end{array}$ 0.050 .36 0.060 .36 0.080 .38 0.060 .25
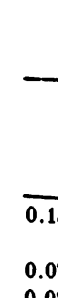

\pm Calculated from the estimations of sodium, potassium, calcium, and magnesium. 


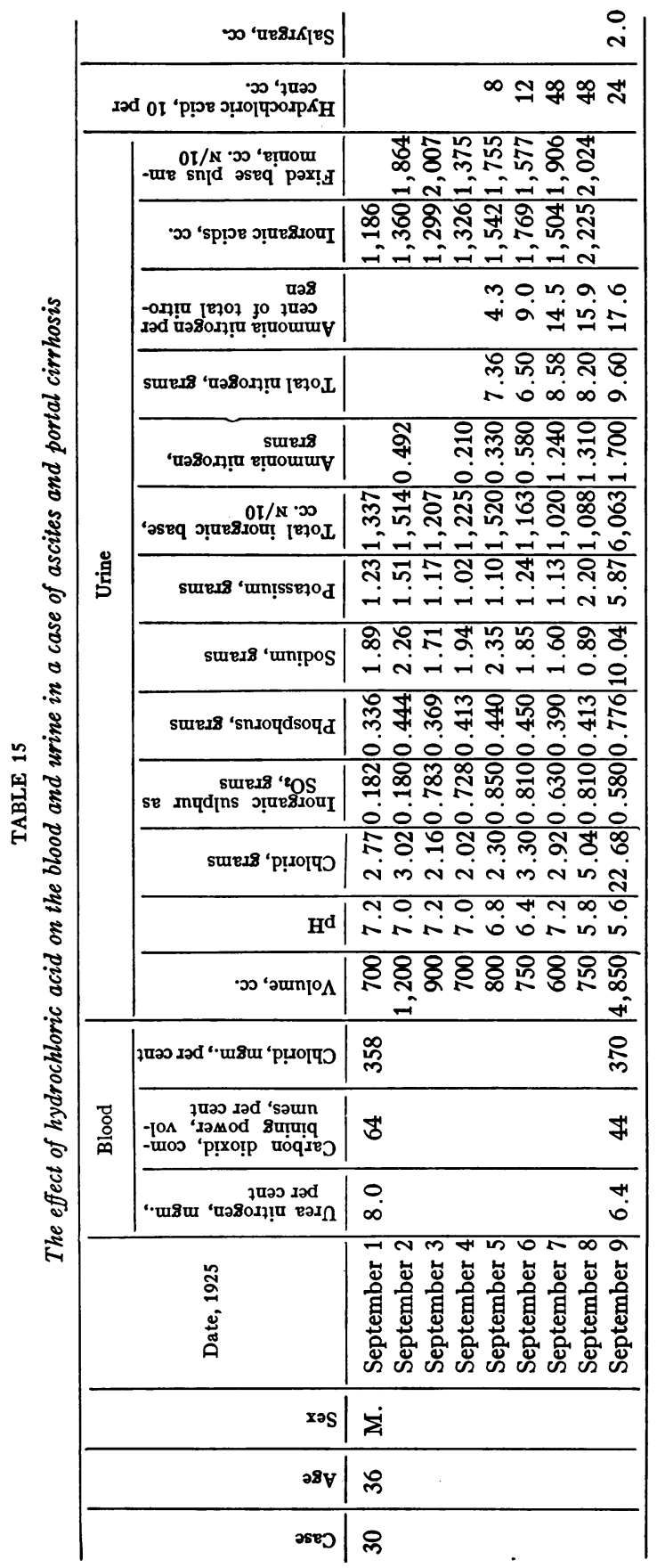


largest output of urine occurred in cases 22,24 and 25 (table 14). In a period of between two and three weeks the actual volume of urine excreted daily by each of these patients on days of diuresis only, amounted to from 16.5 to 30 liters. In case 25 (table 14) the actual loss of weight during the five to six weeks of treatment was 70 pounds ( $31.8 \mathrm{kgm}$.), and is mentioned to demonstrate the possibility of repeated marked diuresis in removing retained fluid from the body. On the other hand, two patients (cases 17 and 18, tables 10 and 13, fig. 6), showed no diuresis when the plasma chlorid level was below normal. The amount of mercury excreted in the urine by each of four patients on days of diuresis, when undergoing the combined treatment, was found to range from 48.5 to 81.3 per cent of that injected. The hydrogen-ion concentration of the urine showed no characteristic changes, though minor variations occurred. The chlorids excreted, except by patients with an abnormally low content of plasma chlorid, always showed a sustained or increased concentration, 0.36 to 0.70 gram per cent, and marked total increase. The maximal output of chlorid occurred in case 25 (table 14), 32.8 grams in twenty-four hours. Similarly, the sodium excreted showed an increased or sustained concentration, 0.05 to 0.44 gram per cent, and large total increase. The evenly sustained excretion of chlorid and sodium at a high level, during this twenty-four-hour period is of note. In case 25 when the amount of chlorid excreted in one period of twenty-four hours amounted to 32.8 grams the sodium excreted totalled 21.3 grams. Thus, on that particular day of the diuresis, total amounts of chlorid and sodium were excreted in the proportions of $6: 4$, the ratio of the two ions in the salt, sodium chlorid. We shall point out that such a ratio of the ions does not always occur. Potassium is usually excreted at a lower concentration during days of diuresis, but the total output is sustained or increased. The variations in the excretion of potassium, particularly in relation to the excretion of chlorid and sodium, are well exemplified during two periods of diuresis, August 16 and 18, in case 25 (table 14). In the two experiments the total volume of urine was the same and the total chlorid differed by only 2 grams, whereas the sodium differed by 10 grams and the potassium by 3.7 grams. Thus when the chlorid excreted was stationary, there was a fall of 10 grams in the sodium 
but an increase of 3.7 grams in the potassium. Whereas in the first experiment almost all the chlorid was excreted as sodium chlorid, in the second the total excretion of sodium and potassium combined did not furnish sufficient base for the large output of chlorid. The

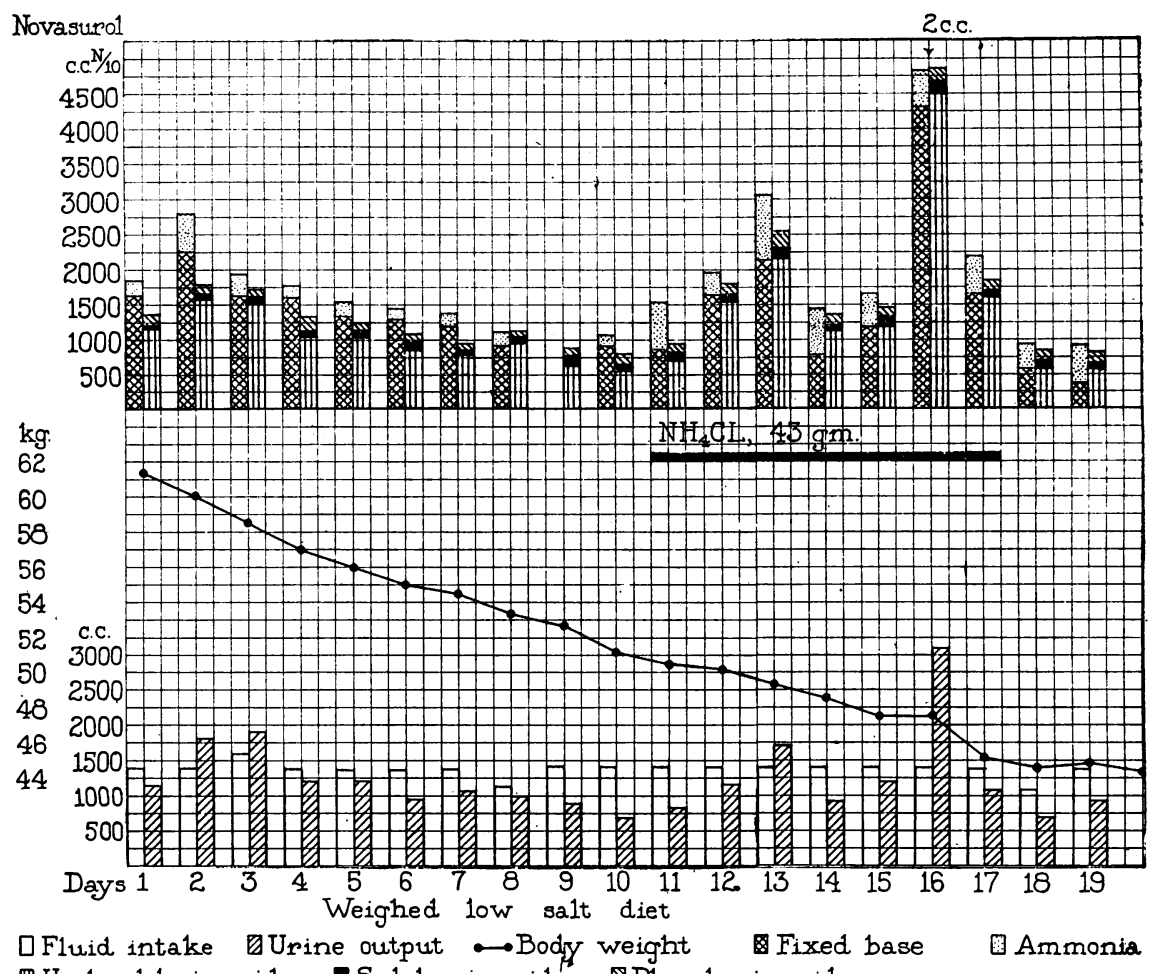

m Hydrochloric acid Sulphuric acid $\mathbb{Q}$ Phosphoric acid

Fig. 3. Chronic Nephrosis. Relative Diuretic Effect of Ammonium Chilorid Alone and Ammonium Chlorm Plus Novasurol; also the Sum of the Inorganic Acid and Inorganic Basic Ions Plus Ammonia in the Urine Calculated as One-tenth Normal Cubic Centimeters, Acid or Alkali. (Case 4, Tables 3, 4, 13 and 14)

ammonium radical unfortunately was not determined. The ammonia excreted was always less concentrated on the days of diuresis, whether the total amount was slightly decreased, maintained the same, or slightly increased. The total fixed base was always markedly increased and the concentration maintained or raised, thus paral- 
leling the chlorid excreted. The total calcium excreted was invariably increased and the magnesium also usually. The sulphate output showed a fall in concentration with a small increase in total amount. A fall in concentration with the total output unchanged was characteristic of the phosphate excretion, a result similar to that noted with

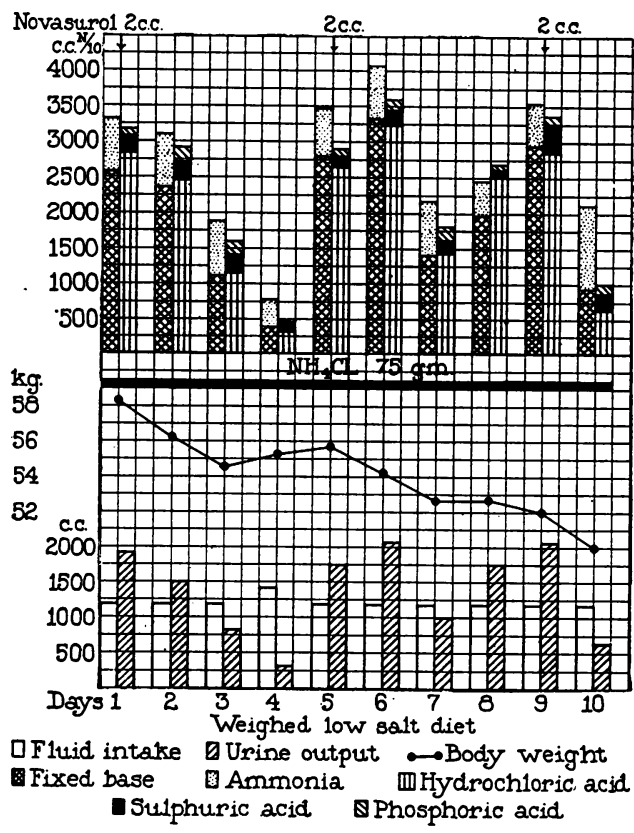

Fig. 4. Chronic Endocarditis and Polycythemia. Prolonged, Combined Diuretic Effect of Ammontum Chiorid and Novasurol; also the Sum of the Inorganic Acid and Inorgantc Basic Ions Plus Ammonia in the Urine Calculated as One-Tenth Normal Cubic Centimeters, Acid or Alkali. (CASE 7, TABles 13 and 14)

novasurol alone. Similarly also there were no constant changes observed in the output of urea or total nitrogen.

Comparison of the excretion of the total inorganic acid ions, with the inorganic basic ions and ammonia, expressed as one-tenth normal acid or alkali, in a normal subject (case 8 , table 14, fig. 2) shows a preponderance of the inorganic acid ions. A similar finding, but with increase of acid over base less marked, was noted in case 4 (table 14, 


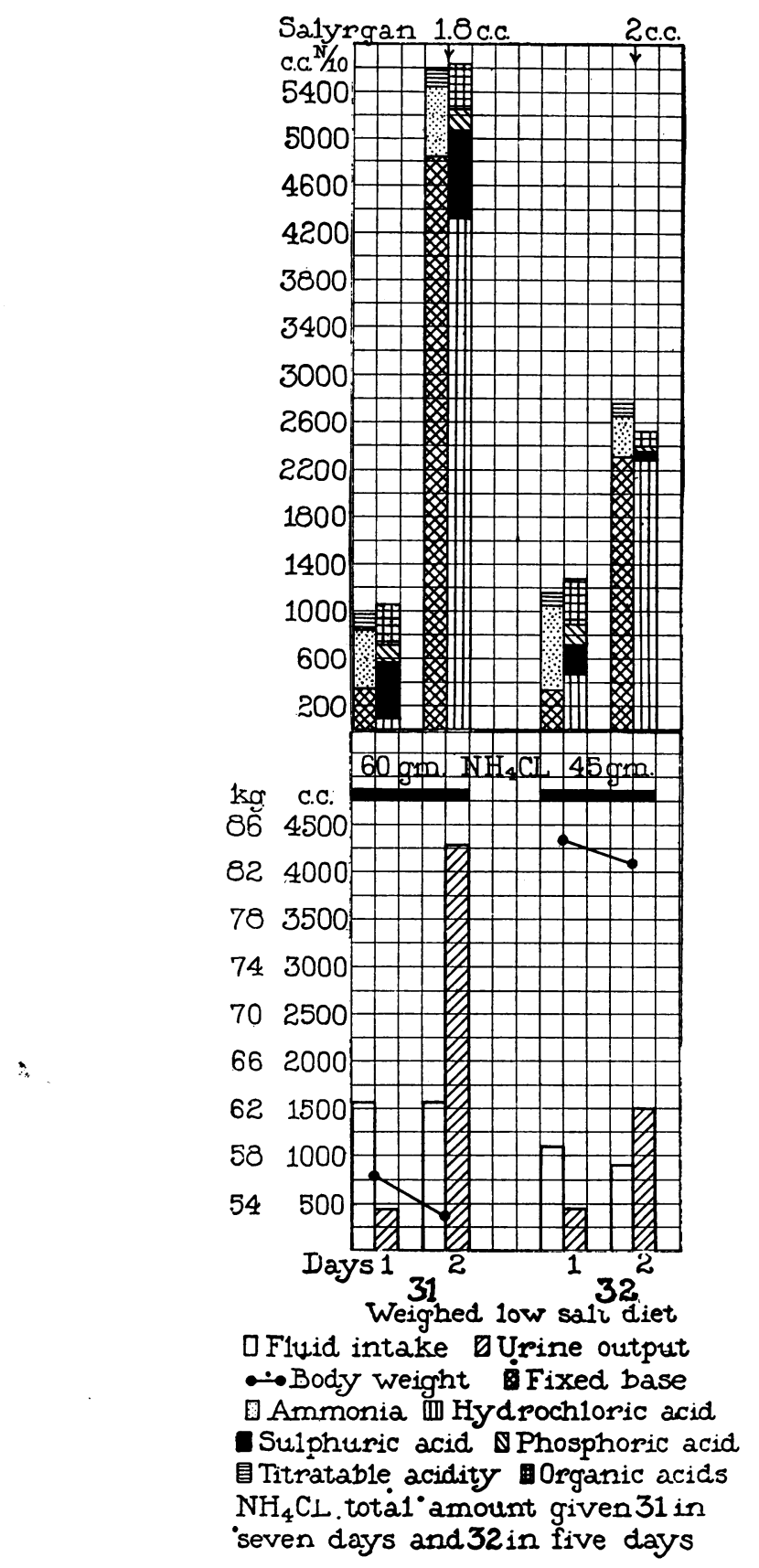

Fig. 5. Relation of the Sum of Acid and Basic Ions in the Urine Calculated as One-tenth Normal Cubic Centimeters, ACI and Alkali. (CAses 31 and 32, Table 16) 


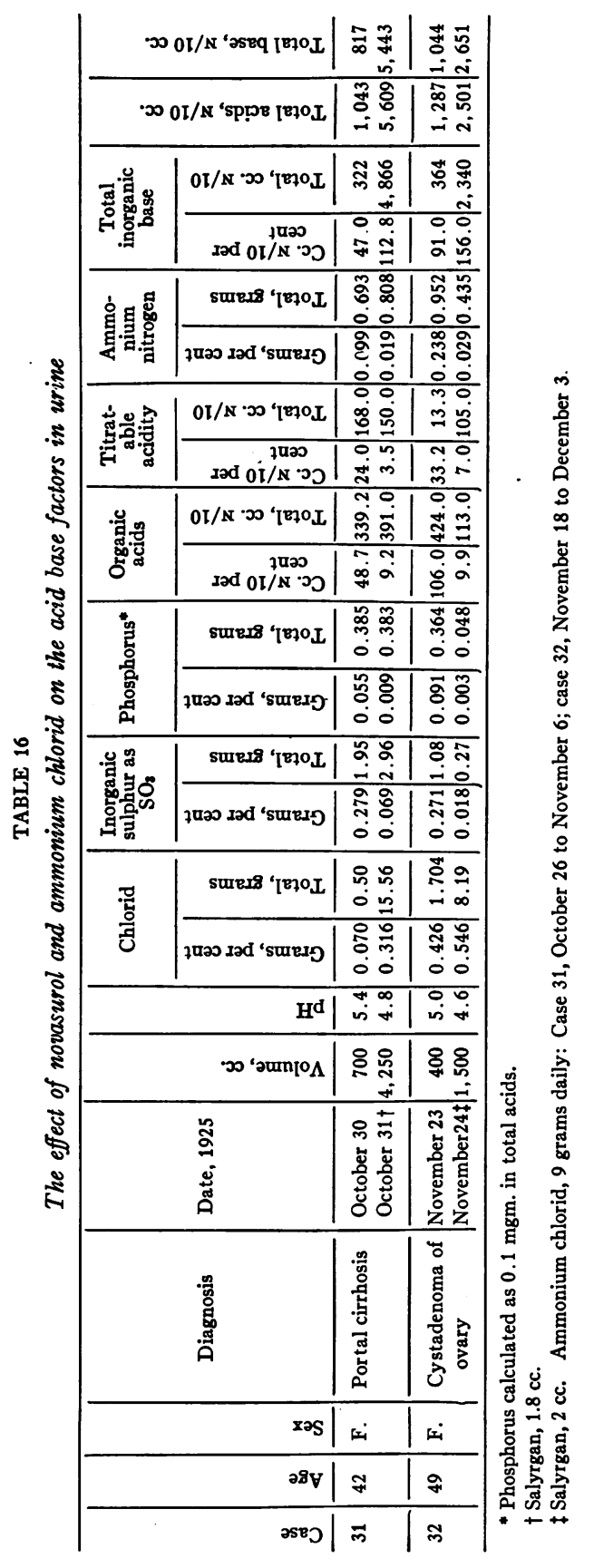


fig. 3). In case 7 (fig. 4) and case 24 (table 14), the total inorganic acid closely approximated the total basic ions. The phosphate ion was calculated as one-tenth molar solution, it thereby having been assumed that it had bound one equivalent of base.

Two patients with marked ascites (case 31 and 32) with only an occasional trace of albumin in the urine manifested definite diuresis after the combined treatment. The titratable acid, and total organic acids were determined in addition to the total inorganic acid, basic ions and ammonia (table 16 and fig. 5). The amount of the total acid excreted closely parallels that of the total base and the titratable acid. These results again emphasize the importance of the specific excretion of chlorid along with fixed base when diuresis is produced by the combined action of ammonium chlorid and organic mercury compounds.

\section{OTHER DIURETICS}

The urinary findings of two patients with diuresis after the use of theocin, digitalis, and novasurol are recorded in table 17 . In the diuresis produced by theocin and digitalis there is an increase in chlorid, sodium and fixed base similar to that produced by novasurol. Steyrer reported diuresis with increase in the chlorid excreted following the administration of digitalis to a patient with cardiac decompensation. Katsuyama and Pototzski noted that after caffein derivatives had been administered to rabbits, the chlorid and sodium excreted in the urine were increased. Bock found that, besides the increase in the chlorid and sodium, the potassium content of the urine was increased during caffein diuresis. Meinertz first reported an increase in the chlorid excreted after the use of caffein derivatives in clinical cases of edema. In the single case in this series in which all three diuretic agents were administered (case 14, table 17), novasurol brought about the maximal excretion of chlorid, sodium and fixed base, although the amount of water excreted equaled that after digitalis. Jendrassik, in $1891,{ }^{6}$ gave calomel to a series of patients

${ }^{6}$ Jendrassik's advocacy of the use of calomel for its diuretic effect was based on certain remarkable instances of diuresis obtained in cases of obstinate edema in Wagener's clinic in Budapest. The calomel treatment for edema was given a trial in numerous clinics at this period, but because of the coexisting diarrhea, and at times harmful effects on the kidney, its use as a diuretic was generally abandoned. 


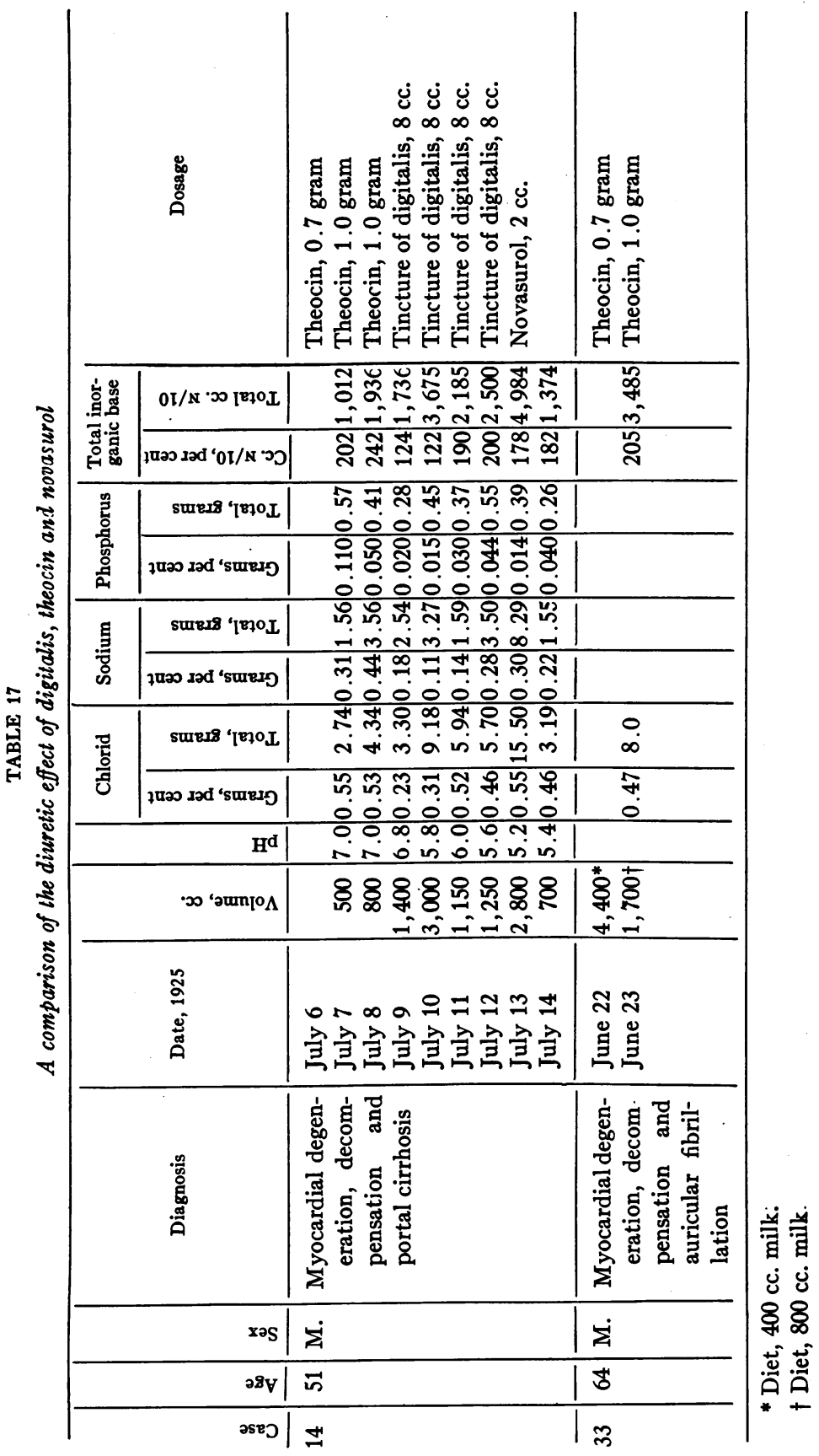


with cardiac edema and noted a similar increase in the urinary excretion of water and chlorids.

Comparative findings in the blood and urine. In three patients with marked edema (cases 7, 22 and 24, table 14) who were given the combined treatment a great diuresis occurred when the carbon dioxid combining-power of the plasma was very slightly below the normal, 48 per cent by volume, and the blood urea was within normal limits, but the plasma-chlorid level was definitely increased. Urinalysis revealed: (1) acidity of the urine with little if any change in hydrogen-ion concentration, from the previous day, (2) marked increase in chlorid, sodium and total fixed base, (3) a small but definite increase in ammonia, (4) very close balance between the total inorganic acid ions, and those of the total inorganic base with ammonia included, and (5) in one case (case 22) an increase in the urea and total nitrogen. The only distinct difference between these results and those of the normal subject (case 8, table 14) is the absence in the former cases of a distinct decrease in the alkali reserve of the plasma.

Cases 17 and 18 (tables 10 and 13) clearly show the close relationship between a low level of plasma chlorid and the consequent low urinary excretion of chlorid and the diuretic action of novasurol. With the level in the plasma below normal and in the presence of marked edema, practically no excretion of chlorid occurred nor did diuresis take place, but when the content was raised to the normal level in case 18 by administering ammonium chlorid, chlorid, fixed base and water were excreted in large amounts. There was no definite relationship between decreased alkali reserve in the plasma and active diuresis, the latter occurring when the former varied between 37.5 and 76 per cent by volume (fig. 6).

The effect of sodium chlorid, as contrasted with that of ammonium chlorid, in an organism which tends to retain fluid readily, is well shown in case 25 (table 14). The patient's weight had been reduced from 84 to $53 \mathrm{kgm}$. (185 to 117 pounds) by the combined use of ammonium chlorid and novasurol. For three days he was given a total of 24 grams of sodium chlorid, but the volume of the urine and the chlorid, sodium, and fixed base excreted remained approximately stationary, nor did the low plasma chlorid show any change. The patient gained $2.4 \mathrm{kgm}$. in weight. These results clearly indicate 
that sodium chlorid in this case passed readily to and lodged in the tissues generally, carrying with it a certain amount of water; hence the increase in weight. This clinical experiment closely parallels that reported by Widal and Javal in a case of edema with chronic nephrosis.

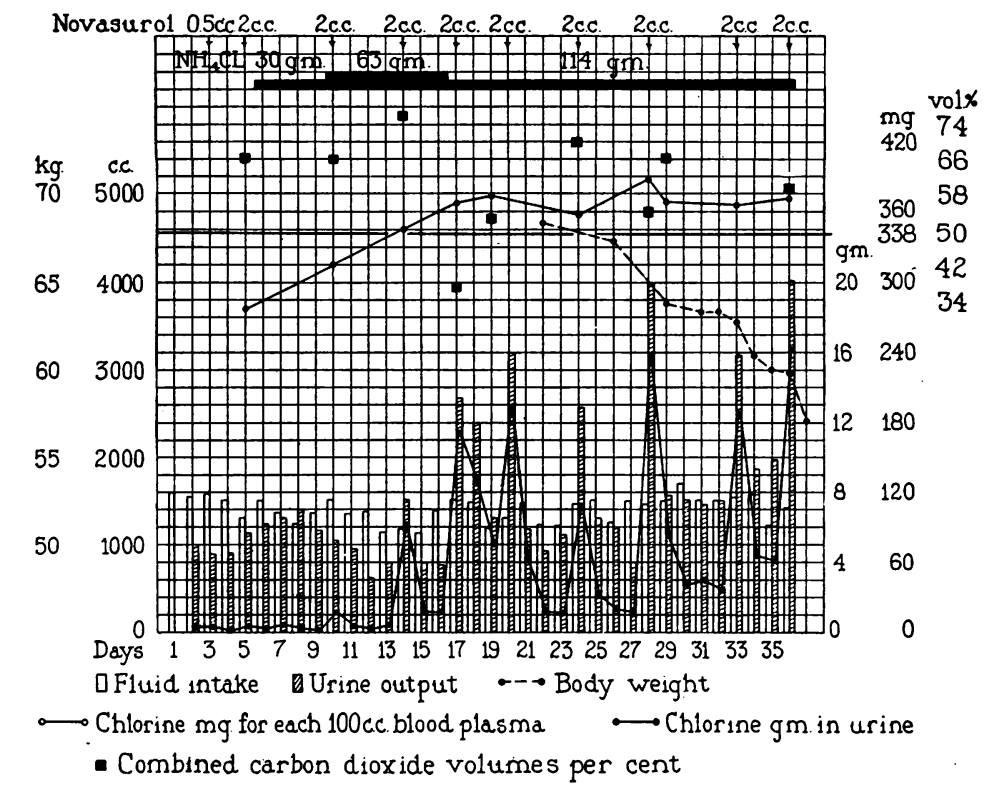

Fig. 6. Relationship of an Abnormally Low and Normal Plasma Chlorm to the Diuresis Produced by Ammonium Chlorm and Novasurol.

(Case 18, Tables 10, 13 and 14)

\section{DISCUSSION}

Action of ammonium chlorid. Following the injection or absorption of this salt the ammonium ions are rapidly synthesized into urea with consequent increase in the blood urea and the urea excretion. The ammonium ions are thus rapidly removed from the blood and tissues leaving hydrochloric acid which causes a shift of the buffer systems toward the acid side. Haldane and Gamble have stressed the chlorid acidosis as the important factor in the causation of the diuresis. Besides the acidosis, we have been led to consider the increase of urea 
and the increase per se of chlorid in the blood and tissues, as possible factors in inducing diuresis.

If the resulting acidosis is the sole cause of the diuretic action of ammonium chlorid the ingestion of acids should have a similar effect. Begun, Herrmann and Münzer studied the effect of the ingestion of a 12.3 per cent solution of hydrochloric acid, 170 and 85 cc., respectively, in two normal men. During the period of acid ingestion they observed an increase in the excretion of chlorid, ammonia nitrogen and titratable acid in the urine. In one case there was no diuresis, and in the other the moderate increase in the volume of urine was due to an increase in the intake of water. One of our patients (case 30, table 15) was given, by mouth, $116 \mathrm{cc}$. of 10 per cent hydrochloric acid, in daily amounts varying from 8 to $48 \mathrm{cc}$. for four days. This amount of hydrochloric acid contains 11.3 grams chlorin, equal to that in 16.5 grams of ammonium chlorid. The ingestion of the acid caused a very slight increase in the plasma chlorid and decrease in carbon dioxid combining-power of the plasma. Studies of the urine showed that the acid had no definite diuretic action. The excretion of chlorid and ammonia was increased. Sodium and potassium showed some variation for it seemed that an increase in sodium was accompanied by a decrease in potassium and vice versa, while the total fixed base excretion remained constant. In this experiment the acid ingestion produced evidences of acidosis without diuresis; however, the lack of increase in the volume of the urine may have been due to the relatively small amount of acid ingested. These results with hydrochloric acid and the fact that the normal subject (case 8) developed acidosis without diuresis in three days after taking 31.5 grams of ammonium chlorid, indicate clearly that acidosis can be produced by chlorid without a parallel increase in the volume of urine. Further experiments with other inorganic acids as sulphuric and nitric acids, are needed to decide the question as to whether such disturbance in the acid-base equilibrium towards the acid side in the tissues will cause liberation of water. In interpreting such experiments the possible specific action of the anion must also be considered.

An abnormally low level of plasma chlorid with little or no chlorid excreted in the urine has been demonstrated in cases of severe renal 
insufficiency with and without demonstrable edema, lobar pneumonia, extensive superficial burns, war-gas poisoning, the toxic syndrome associated with upper intestinal obstruction, and in two cases of portal cirrhosis with edema and ascites in this series (cases 17 and 18 , table 10). In one of the latter (case 18) when the ascites and edema were extensive the ingestion of ammonium chlorid gradually raised the lowered chlorid plasma threshold to the normal level and thus permitted an increase in excretion through the kidney.

At first glance the administration of a chlorid in large amounts to an organism literally loaded down with chlorids and water seems most illogical. However, it proved to be a life-saving measure in the case just described. The exact manner in which the chlorid current was thus diverted from the general tissues toward the blood stream and hence through the kidney is not easily explained. Sodium chlorid had no such effect in case 25 (table 14). On the other hand, it augmented the current of chlorid and water toward the tissues. This simple clinical experiment shows the important relationship between retained sodium and retained water, as pointed out by Meyer and Blum. Besides the acidity factor, due to ammonium chlorid, the status quo of the ions already present, and the specific action of the chlorid ion itself must also play a part in causing such an important shift in the movement of the body fluids.

Action of organic mercury compounds. A large percentage of the injected mercury is excreted in the urine. Diuresis is accompanied by an increased excretion of chlorid and fixed base. The latter is chiefly due to the increased elimination of sodium although potassium in certain instances made up a considerable fraction. The urine excreted the day following diuresis contained small amounts of chlorid and sodium, but the average amount of potassium. The latter urinary findings are similar to those noted by Benedict during starvation, in which condition there is known to be a retention of chlorid and sodium. There was no conclusive evidence during this diuresis of any marked change in the acid-base equilibrium of the blood or urine. We did note the absence of diuresis when the plasma chlorid content was well below the normal threshold. Further we have been unable to show any constant changes in the composition of the blood during the period when a large quantity of fluid must 
necessarily be liberated from the tissues and transported within the organism. These negative findings are in harmony with those of Haldane and Priestley in the blood of normal man after the ingestion of a large quantity of water. Greene and Rowntree had to give a much larger amount of water to animals to produce changes in blood concentration. The liberation of ascitic fluid by organic mercury compounds in cases of serious hepatic disease without any demonstrable renal impairment would lead one to believe that the specific action was in the tissues remote from the kidneys. The specific action in renal edema suggests an effect both on the general tissues and kidneys. Experiments on the perfused isolated kidney might be crucial in determining the specific site of action.

Combined action of ammonium chlorid and organic mercury compounds. Following the combined administration of ammonium chlorid and organic mercury compounds, marked diuresis was the rule. The diuresis occurred more consistently than before, when the diuretic substances were given singly, and large accumulations of fluid within the body were removed in a comparatively short period. Both substances have the same fundamental property of removing chlorid and fixed base as well as water from the organism, and their combined action may thus be simply a cumulative one. Full diuresis did occur when the blood plasma values for urea, chlorid and the carbon dioxid combining-power were normal. However, even with the normal plasma content of urea, chlorid and carbon dioxid combining-power, the urinary findings showed an increased excretion of ammonia which indicated definite acidosis. Such results point to a possible compensatory regulation of the acid-base equilibrium in the plasma when the tissues are still more acid in reaction than normal. Thus the acidosis produced by an acid-forming salt, after a long period of ingestion, may be closely analogous to a case of compensated acidosis in diabetes mellitus. In our experience novasurol alone did not cause a demonstrable change in the acid-base equilibrium of the body, whereas when combined with ammonium chlorid there was always evidence, in the plasma or urine, of acidosis. We have thus demonstrated that ammonium chlorid can produce acidosis in the organism with or without diuresis; that novasurol can bring about diuresis when there is no acidosis; and that the combined 
exhibition of ammonium chlorid and novasurol causes the most marked diuresis when acidosis is present. From such facts one must conclude that an abnormal acid reaction in the tissues need not per se cause diuresis, but since it ocurs when the diuretic response is most regular and marked, it must be considered a possible factor in liberating water from the tissues.

When diuresis follows the use of the caffein diuretics and digitalis the urine shows a decided increase in the chlorid and fixed base excreted. If acidosis favors diuresis, the combined use of an acidforming salt and theocin, for example, might cause diuresis after theocin alone has failed. We are at present carrying out some experiments to test this possibility.

Urea has long been recognized as possessing diuretic properties and has been used as a therapeutic agent in different types of edema. Crawford and McIntosh have lately reported beneficial effects from its use in cases of cardiac edema. Their results show clearly that the increased elimination of water is accompanied by an increased excretion of urea, but with only slight irregular increases in chlorids. Here then the mechanism of diuresis is quite distinct from that involved when ammonium chlorid or an organic mercury compound, caffein or digitalis, is administered. Similarly, hypertonic solutions of glucose and saccharose have been employed experimentally to produce marked diuresis and subsequent dehydration. Some of our unpublished data indicate that, like urea, these sugars may not necessarily cause a distinctly increased excretion of chlorid and fixed base. From a practical therapeutic standpoint those substances which remove water, chlorid, and fixed base from edematous patients remove both the retained fluid and its inorganic dissolved constituents and therefore accomplish a more complete withdrawal than diuretics of the urea and sugar type.

The removal of accumulated fluid, in cases of cardiac and nephritic edema, and in cases of ascites associated with disease of the liver, is a fundamental problem in therapeutics. This excess fluid is either retained within the cells themselves, in the tissues or in the body cavities. It may leave the cells, tissues or body cavities spontaneously. Digitalis, the caffein derivatives, acid-forming salts, organic mercury compounds or urea may bring about diuresis when it does not 
occur spontaneously. The site of action of these diuretics would seem to be diffuse and not limited to one specific organ, the kidney. The exact quantitative levels at which salts can pass from the edematous tissues into the blood stream and from the blood stream through the kidney may be affected by these drugs. That abnormal levels do exist in edematous conditions and can be altered has been well shown in cases of this series. These diuretics may also act by permitting salts and water to pass through cells previously impervious, as the renal cell in oliguria and the peritoneal endothelium in the ascites of cirrhosis of the liver.

\section{SUMMARY}

Following the administration of ammonium chlorid and its absorption into the blood stream it has been shown experimentally that the ammonia is quickly synthesized to urea. The liberated hydrochloric acid increases the chlorid content of the blood and tissues with the production of acidosis. Under the conditions of these experiments diuresis may or may not occur after the exhibition of an adequate amount of ammonium chloride. Ammonium chlorid in man causes an increased excretion of chlorid, fixed inorganic base (particularly sodium and potassium), ammonia, urea, and total nitrogen in the urine.

Organic mercury compounds cause an increased excretion of chlorid and inorganic fixed base, without evidence in the blood or urine of a change in acid-base equilibrium. The basic ions, sodium and potassium, may be excreted independently. Diuresis occurs usually but not always. Changes in the concentration of the blood are inconstant and never marked in degree, even when the diuresis is great. Eighty-five per cent of the injected mercury can be recovered in the subsequent twenty-four-hour specimen of urine.

Ammonium chlorid and organic mercury compounds used in combination produce diuresis when singly they fail to do so. They cause acidosis, an increase in the chlorid content of the blood, and an increase in the excretion of water, chlorid, fixed inorganic base, chiefly sodium and potassium, and ammonia. In one case in which there was a subnormal plasma chlorid level the combined drugs failed to 
produce diuresis. Ammonium chlorid was then given until the chlorids reached the normal level, when organic mercury produced satisfactory diuresis.

The evidence at hand indicates that the activity of these diuretics is not limited to the kidney, but that extrarenal factors enter into consideration.

\section{BIBLIOGRAPHY}

1. Baird, N. M., Douglas, C. G., Haldane, J. B. S., and Priestley, J. G.: Jour Physiol., 1922-1923, lvii, xli. Ammonium Chloride Acidosis.

2. Begun, A., Herrmann, R., Münzer, E.: Biochem. Ztschr., 1915, lxxi, 255-267. Über Acidosis und deren Regulation im menschlichen Körper.

3. Bell, R. D., and Doisy, E. A.: Jour. Biol. Chem., 1920, xliv, 55-67. Rapid Colorimetric Methods for the Determination of Phosphorus in Urine and Blood.

4. Benedict, F. G.: Washington, D. C., Carnegie Institute, 1915, No. 203, p. 285. A Study of Prolonged Fasting.

5. Bleyer, Leo: Klin. Wchnschr;, 1922, i, 1940-1942. Erfahrungen über die Novasurol-diurese.

6. Blum, L.: Verhandl. d. Kong. f. inn. Med., 1909, 122-126. Ueber die Rolle von Salzen bei der Enstehung von Oedemen.

7. Bock, J.: Skandinav. Arch. f. Phys., 1911, xxv, 239-246. Utber die Ausscheidung der Alkalimetalle bei der Purindiurese.

8. Bohn, Hans: Klin. Wchnschr., 1923, ii, no. 1, 352-353. Experimentalle Studien über die diuretische Wirkung des Novasurols.

9. Bollman, J. L., Mann, F. C., and Magath, T. B.: Amer. Jour. Physiol., 1924, lxix, 371-392. Studies on the Physiology of the Liver. VIII. Effect of Total Removal of the Liver' on the Formation of Urea.

10. Boothby, W. M., and Sandiford, Irene: Philadelphia, Saunders, 1920, 117 pp. Basal Metabolic Rate Determinations.

11. Briggs, A. P.: Jour. Biol. Chem., 1922, liii, 13-16. A Modification of the Bell-Doisy Phosphate Method.

12. Crawford, J. H., and McIntosh, J. F.: Arch. Int. Med., 1925, xxxvi, 530541. The Use of Urea as a Diuretic in Advanced Heart Failure.

13. Crawford, J. H., and McIntosh, J. F.: Jour. Clin. Invest., 1925, 1, 333-358. Observations on the Use of Novasurol in Edema Due to Heart Failure.

14. Fiske, C. H.: Jour. Biol. Chem., 1922, li, 55-61. A Method for the Estimation of Total Base in Urine.

15. Folin, Otto: Jour. Biol. Chem., 1905, i, 150-159. The Determination of Sulphates and Total Sulphur in Urine.

16. Folin, Otto, and Bell, R. D.: Jour. Biol. Chem., 1917, xxix, 329-335. Applications of a New Reagent for the Separation of Ammonia. I. The Colorimetric Determination of Ammonia in Urine. 
17. Folin, Otto, and Wu, Hsien: Jour. Biol. Chem., 1919, xxxviii, 81-110. A System of Blood Analysis.

18. Gamble, J. L., Blackfan, K. D., and Hamilton, Bengt: Jour. Clin. Invest., 1925, i, 359. A Study of the Diuretic Action of Acid Producing Salts.

19. Gillespie, L. J.: Amer. Chem. Soc. Jour., 1920, xlii, 742-748. Colorimetric Determination of Titration Curves Without Buffer Mixtures.

20. Greene, C. H., and Rowntree, L. G.: Amer. Jour. Physiol., 1924, lxviii, 111. Changes in the Concentration of the Blood Following the Administration of Excessive Quantities of Water.

21. Haden, R. L.: Jour. Lab. and Clin. Med., 1923, viii, 411-414. A Method for the Determination of Hemoglobin.

22. Haldane, J. B. S.: Jour. Physiol., 1921, lv, 265-275. Experiments on the Regulation of the Blood's Alkalinity.

23. Haldane, J. B. S., and Priestley, J. G.: Jour. Physiol., 1915-1916, 1, 296303. The Regulation of Excretion of Water by the Kidneys. I.

24. Harvey, S. C.: Arch. Int. Med., 1910, vi, 12-18. The Quantitative Determination of the Chlorids in the Urine.

25. Jendrássik, E.: Deutsch. Arch. f. klin. Med., 1885-1886, xxxviii, 499-524. Das Calomel als Diureticum.

26. Jendrássik, E.: Deutsch. Arch. f. klin. Med., 1890-1891, xlvii, 226-288. Weitere Untersuchungen über die Quecksilberdiurese.

27. Katsuyama, K.: Ztschr. f. physiol. Chem., 1899, xxviii, 587-594. Ueber der Einfluss des Theins auf die Ausscheidung von Alkalien im Harne.

28. Katsuyama, K.: Ztschr. f. physiol. Chem., 1901, xxxii, 235-240. Ueber den Einfluss einiger harntreibender Mittel auf die Ausscheidung von Alkalien im Harne.

29. Keith, N. M.: Amer. Jour. Physiol., 1924, lxviii, 80-96. Experimental Dehydration: Changes in Blood Composition and Body Temperature.

30. Keith, N. M., Barrier, C. W., and Whelan, Mary: Jour. Amer. Med. Assn., 1925, lxxxv, 799-806. The Diuretic Action of Ammonium Chlorid and Novasurol in Cases of Nephritis with Edema.

31. Keith, N. M., Smith, Florence, and Whelan, Mary: Arch. Int. Med., 1926, xxxvii, 550-558. The Therapeutic Use of Diets Low in Water and Mineral Content.

32. Keith, N. M., and Thomson, W. W. D.: Quart. Jour. Med., 1918, xi, 229266. War Nephritis. A Clinical, Functional and Pathological Study.

33. Keith, N. M., and Whelan, Mary: Amer. Jour. Physiol., 1925, lxxii, 195-196. The Effect of Novasurol on the Composition of Blood and Urine.

34. Kramer, Benjamin, and Tisdall, F. F.: Jour. Biol. Chem., 1921, xlvi, 339349. A Clinical Method for the Quantitative Determination of Potassium in Small Amounts of Serum.

35. Kramer, Benjamin, and Tisdall, F. F.: Jour. Biol. Chem., 1921, xlvi, 467473. A Simple Method for the Direct Quantitative Determination of Sodium in Small Amounts of Serum. 
36. Kramer, Benjamin, and Tisdall, F. F.: Jour. Biol. Chem., 1921, xlvii, 475481. A Simple Technique for the Determination of Calcium and Magnesium in Small Amounts of Serum.

37. Lewis, D. S., and Rivers, T. M.: Bull. Johns Hopkins Hosp., 1916, xxvii, 193-201. Chemical Studies on a Case of Bichloride Poisoning.

38. MacCallum, W. G., Lintz, Joseph, Vermilye, H. N., Leggett, T. H., and Boas, E.: Bull. Johns Hopkins Hosp., 1920, xxxi, 1-7. The Effect of Pyloric Obstruction in Relation to Gastric Tetany.

39. Meinertz, J.: Therap. Monatsh., 1904, xviii, 275-285. Versuche über Diurese insbesondere über die Wirkung des Theocinnatrium aceticum.

40. Meyer, L. F.: Verhandl. d. Versamml. d. Gesellsch. f. Kinderh., 1909, xiv.

41. Moraczewski, v. W.: Arch. f. path. Anat. u. Physiol. u. f. klin. Med., 1896, cxlvi, 424-452. Ueber den Chlor- und Phosphorgehalt des Blutes bei krankhaften Zuständen.

42. Mühling, Adolf: München. med. Wchnschr., 1921, lxviii, no. 2, 1447-1449. Studie über die diuretische Wirkungsweise von Quicksilber. Ausgeführt mit dem organischen Quecksilberpräparat Novasurol.

43. Nash, T. P., and Benedict, S. R.: Jour. Biol. Chem., 1921, xlviii, 463-488. The Ammonia Content of the Blood, and Its Bearing on the Mechanism of Acid Neutralization in the Animal Organism.

44. Nonnenbruch, W.: München. med. Wchnschr., 1921, lxviii, ii, 1282-1283. Ueber die Wirkung des Novasurols auf Blut und Diurese.

45. Potozky, C.: Arch. f. d. ges. Physiol., 1902, xci, 584-594. Beiträge zur Diurese. Ueber den Einfluss einiger Diuretica auf die Kochsaltzausscheidung, insbesondere beim kochsalzarmen Thiere.

46. Priestley, J. G.: Jour. Physiol., 1915-1916, 1, 304-311. The Regulation of Excretion of Water by the Kidneys. II.

47. Rowntree, L. G., Keith, N. M., and Barrier, C. W.: Jour. Amer. Med. Assn., 1925, lxxxv, 1187-1193. Novasurol in the Treatment of Ascites in Hepatic Disease.

48. Saxl, P., and Heilig, R.: Wien. klin. Wchnschr., 1920, xxxiii, 943. Ueber die diuretische Wirkung von Novasurol- und anderen Quecksilberinjektionen.

49. Smith, Millard: Jour. Biol. Chem., 1921, xlv, 437-447. The Determination of Chlorides in Trichloro-acetic Acid Filtrates from Whole Blood and Plasma.

50. Steyrer: Beitr. z. chem. Physiol. u. Path., 1902, ii, 312. Über osmotische Analyse des Harns.

51. Tisdall, F. F., and Kramer, Benjamin: Jour. Biol. Chem., 1921, xlviii, 1-12. Methods for the Direct Quantitative Determination of Sodium, Potassium, Calcium and Magnesium in Urine and Stools.

52. Underhill, F. P.: The Lethal War Gases. New Haven, Yale University Press, 1920. 
53. Underhill, F. P., Carrington, G. L., Kapsinow, Robert, and Pack, G. T.: Arch. Int. Med., 1923, xxxii, 31-49. Blood Concentration Changes in Extensive Superficial Burns, and Their Significance for Systemic Treatment. 54. Van Slyke, D. D., and Cullen, G. E.: Jour. Biol. Chem., 1914, xix, 211-228. A Permanent Preparation of Urease, and Its Use in the Determination of Urea.

55. Van Slyke, D. D., and Palmer, W. W.: Jour. Biol. Chem., 1920, xli, 567-585. Studies on Acidosis. XVI. The Titration of Organic Acids in Urine.

56. Van Slyke, D. D., and Stadie, W. C.: Jour. Biol. Chem., 1921, xlix, 1-42. The Determination of the Gases of the Blood.

57. Whelan, Mary: Jour. Biol. Chem., 1925, lxiii, 585-620. The Effect of Intravenous Injection of Inorganic Chlorides on the Composition of Blood and Urine.

58. Widal, F., and Javal, A.: Bull. et mém. Soc. de méd. d. hôp. de Par., 1903, 3 s., $x x, 733-749$. La cure de déchloruration; son action sur l'oedème, sur l'hydration et sur l'albuminurie à certaines périodes de la néphrite épithéliale.

59. Wong, San Yin: Jour. Biol. Chem., 1923, lv, 431-435. The Use of Persulfate in the Estimation of Nitrogen by Folin's Direct Nesslerization Method. 